\title{
NBSIR 77-1200
}

\section{An Evaluation of Fire Properties of Generic Gypsum Board Products}

J. Randall Lawson, Research Associate Gypsum Association

Center for Fire Research Institute for Applied Technology National Bureau of Standards

Washington, D. C. 20234

\section{August 1977}

Final Report

QC 100 456

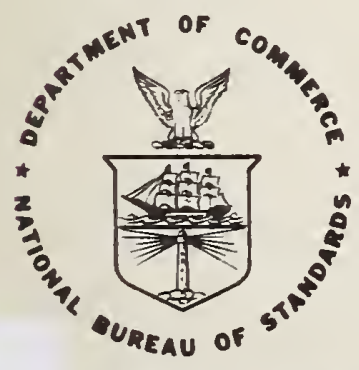

\section{S. DEPARTMENT OF COMMERCE} TIONAL BUREAU OF STANDARDS *77-1265 

NBSIR 77-1265

\section{AN EVALUATION OF FIRE PROPERTIES OF GENERIC GYPSUM BOARD PRODUCTS}

J. Randall Lawson, Research Associate

Gypsum Association

Center for Fire Research

Institute for Applied Technology

National Bureau of Standards

Washington, D. C. 20234

August 1977

Final Report

U.S. DEPARTMENT OF COMMERCE, Juanita M. Kreps, Secretary

Dr. Sidney Harman, Under Secretary

Jordan J. Baruch, Assistant Secretary for Science and Technology

NATIONAL BUREAU OF STANDARDS, Ernest Ambler, Acting Director 

LIST OF FIGURES . . . . . . . . . . . . . . . . . . . . . . . iv

LIST OF TABLES. . . . . . . . . . . . . . . . . . . . . IV

Abstract. . . . . . . . . . . . . . . . . . . . . . 1

1. INTRODUCTION. . . . . . . . . . . . . . . . . . . . . . . . 1

1.1. Potential Heat. . . . . . . . . . . . . . . . . . . 2

1.2. Rate of Heat Release. . . . . . . . . . . . . . . . . . . 2

1.3. Ease of Ignition. . . . . . . . . . . . . . . . . . . 3

1.4. Flame spread. . . . . . . . . . . . . . . . . . . . . 3

1.5. Material Examination by Scanning Electron Microscope -
$13 \mathrm{~mm}(1 / 2 \mathrm{in})$ Type-x Gypsum Board. . . . . . . . . . 3

2. TEST SPECIMENS. . . . . . . . . . . . . . . . . . . . . . 3

2.1. Sampling and Conditioning . . . . . . . . . . . . . . . 5

2.2. Specimen Preparation for the Potential Heat Test. . . . . . . 5

2.3. Specimen Preparation for the Scanning Electron

Microscope observations . . . . . . . . . . . . . . 6

3. TEST APPARATUS AND PROCEDURES . . . . . . . . . . . . . . . . . . . 6

3.1. Standard Test Method for Potential Heat of Building

Materials — NFPA Standard 259-1976... . . . . . . . . . . 6

3.2. Test for Measuring the Rate of Heat Release of

Building Materials - NBS Method. . . . . . . . . . . . . . 7

3.3. Ease of Ignition by Flame Impingement Test Method:. . . . 8

3.4. Surface Flammability of Materials Using a Radiant Panel

(ASTM E I62)...................... . . 10

4. TEST RESULTS AND DISCUSSION . . . . . . . . . . . . . . . . . 11

4.1. Potential Heat Test... . . . . . . . . . . . . . 11

4.2. Rate of Heat Release. . . . . . . . . . . . . . . 13

4.3. Ease of Ignition. . . . . . . . . . . . . . . . . . 15

4.4. Flame spread. . . . . . . . . . . . . . . . . . . . . . . . . 17

4.5. Scanning Electron Microscope study of $13 \mathrm{~mm}(1 / 2 \mathrm{in})$ Type-X Gypsum Board... . . . . . . . . . . . . . . 19

5. SUMMARY . . . . . . . . . . . . . . . . . . . . . . 23

6. ACKNOWLEDGMENTS . . . . . . . . . . . . . . . . . . . . . . 23

7. REFERENCES. . . . . . . . . . . . . . . . . . . . . . . . . 24

APPENDIX - COMPONENT WEIGHT FRACTIONS USED IN THE CALCULATIONS OF POTENTIAL HEAT SHOWN IN TABLE $1 . . .6 . . . . . . .25$ 
Figure 1. Schematic Diagram of Test Procedure for Potential

Heat Measurements . . . . . . . . . . . . 7

Figure 2. NBS Heat Release Rate Calorimeter . . . . . . . . . . 8

Figure 3. Sketch of Ignition Apparatus. . . . . . . . . . . . . . . . 9

Figure 4. Diagrammatic Drawing of a Radiant-Panel Test Method . . . 10

Figure 5. Average Ignition Time (Ignition Test) vs. Heat

Contribution Time Piloted $4 \mathrm{~W} / \mathrm{cm}^{2}$ Exposure (Calorimeter). . 16

Figure 6. Variation in Flame spread E 162 versus E $84 . . . . . . .19$

Figure 7. SEM Picture 120X Type-X Board Core before Fire Exposure • . 21

Figure 8. SEM Picture 800X Type-X Board Core before Fire Exposure • . 21

Figure 9. SEM Picture 2700X Type-X Board Core Gypsum Crystals Not Exposed to Fire . . . . . . . . . . . . . . . . . 21

Figure 10. SEM Picture 120X Type-X Board Core after Fire Exposure. • 21

Figure 11. SEM Picture 500X Type-X Board Core after Fire Exposure. • 22

Figure 12. SEM Picture $160 \mathrm{x}$ Expanded Vermiculite and Melted End of Glass Fiber after Fire Exposure. . . . . . . . . . 23

Figure 13. SEM Picture 2600X Gypsum Crystals of Board after Exposure to Fire... . . . . . . . . . . . . . . . . 22

\section{LIST. OF TABLES}

Table 1. Gypsum Board Potential Heat Test Results -- NFPA 259

Method ...................... 12

Table 2. Gypsum Board Peak Rate of Heat Release. . . . . . . . . 14

Table 3. Gypsum, Board Ease of Ignition Test Results. • . . • . . 15

Table 4. Gypsum Board Surface Burning Characteristics. . . . . . 18 


\section{AN EVALUATION OF FIRE PROPERTIES OF GENERIC GYPSUM BOARD PRODUCTS}

J. Randall Lawson ${ }^{1}$

\section{Abstract}

An evaluation of the fire properties of generic gypsum board products was made in order to obtain a better understanding of the material's reaction to a fire environment. These gypsum board products are typically used in wall and ceiling assemblies throughout the United States. Four small-scale fire test methods were used in the examination of the materials' fire properties. The tests conducted were for potential heat, ease of ignition by flame impingement, rate of heat release, and rate of flame spread. All of these properties are of major importance in the design of a building. They influence the potential rate of fire growth in a room. Standard fire test methods were used for the development of data on rate of flame spread and potential heat characteristics. The ease of ignition and rate of heat release characteristics were determined by fire tests recently developed at the National Bureau of standards. Test results showed that the potential heat for the materials examined ranged from $510 \mathrm{~J} / \mathrm{g}(220 \mathrm{Btu} / \mathrm{lb})$ to $2670 \mathrm{~J} / \mathrm{g}$ (1150 Btu/lb). The ignitability of the materials spanned from 42 to 171 seconds, while the peak heat release averages ranged from a 2.5 to $4.8 \mathrm{~W} / \mathrm{cm}^{2}$ on an unpiloted $4 \mathrm{~W} / \mathrm{cm}^{2}$ exposure and 3.9 to 8.2 $\mathrm{W} / \mathrm{cm}^{2}$ on an unpiloted $6 \mathrm{~W} / \mathrm{cm}^{2}$ exposure. The flame spread index for the materials ranged from 8 to 38 .

Key words: Buildings; ease of ignition; fire tests; rate of flame spread; gypsum board; potential heat; properties; rate of heat release; scanning electron microscope (SEM).

\section{INTRODUCTION}

Gypsum board was first used in construction in the early 1900's. The production and use of the material in building construction grew at a slow rate until the mid-1940's when the demand for housing rapidly increased. At this time, gypsum wallboard (drywall) became the major interior finishing component for walls and ceilings in various types of buildings. Over the last three decades, a family of nine generic board products have evolved with special characteristics in order to meet the needs of the building industry and code regulations (see section 2). At the present time, conventional construction utilizes gypsum board in 90 percent of all buildings in the United States. Gypsum wallboard is generally known for its fire resistive characteristics; however, little technical information is available on the specific fire properties [1] ${ }^{2}$.

Pure Gypsum is "hydrous calcium sulphate," $\mathrm{CaSO}_{4} \cdot 2 \mathrm{H}_{2} \mathrm{O}$, a monoclinic shaped crystalline mineral that contains chemically combined water. The gypsum crystals contain about 50 percent water by volume and about 21 percent by weight. This water of crystallization plays a major role in the thermal properties of the material and controls how it will react to heat and flame.

\footnotetext{
This work was conducted while Mr. Lawson was a research associate for The Gypsum Association at the National Bureau of Standards.

2

2 Numbers in brackets refer to the literature references listed at the end of this paper.
} 
In order to better relate how gypsum reacts to heat, it is necessary to understand its degradation process. The mineral gypsum $\mathrm{CaSO}_{4} \cdot 2 \mathrm{H}_{2} \mathrm{O}$ at temperatures between 0 to $66^{\circ} \mathrm{C}$ ( 32 to $150{ }^{\circ} \mathrm{F}$ ) usually contains a small amount of free moisture absorbed to the surface of the pores. Around $100{ }^{\circ} \mathrm{C}\left(212^{\circ} \mathrm{F}\right)$ the moisture leaves the pores (desorption), then at about $125^{\circ} \mathrm{C}\left(257^{\circ} \mathrm{F}\right)$ gypsum becomes unstable and loses $3 / 4$ of its chemically combined $\mathrm{H}_{2} \mathrm{O}$ from the crystal lattice (dehydration). This yields the material commonly known as plaster of Paris $\mathrm{CaSO}_{4} \cdot 1 / 2 \mathrm{H}_{2} \mathrm{O}$.

$$
\mathrm{CaSO}_{4} \cdot 2 \mathrm{H}_{2} \mathrm{O} \underset{\text { heat }}{\stackrel{125{ }^{\circ} \mathrm{C}}{\longrightarrow}} \mathrm{CaSO}_{4} \cdot 1 / 2 \mathrm{H}_{2} \mathrm{O}+\underset{\text { steam }}{1-1 / 2 \mathrm{H}_{2} \mathrm{O}} \stackrel{\Delta \mathrm{H}-\text { Heat of Hydration }}{15,900 \text { to } 17,160 \text { Joule/Mole }}
$$

Through continued heating, the remaining $\mathrm{H}_{2} \mathrm{O}$ is released through the cell lattice. The water driven off during the heating process carries away heat and helps to retard the flow of heat through the remaining gypsum. At about $360^{\circ} \mathrm{C}\left(680^{\circ} \mathrm{F}\right)$ the soluble anhydrous $\mathrm{CaSO}_{4}$ transforms into an insoluble modification which is stable up to $1227{ }^{\circ} \mathrm{C}\left(2240{ }^{\circ} \mathrm{F}\right)$ when a small amount of $\mathrm{CaSO}_{4}$ dissociates into $\mathrm{CaO}$ and $\mathrm{SO}_{3}$. Finally, at $1382^{\circ} \mathrm{C}\left(2520^{\circ} \mathrm{F}\right)$ the melting of $\mathrm{CaO}-\mathrm{CaSO}_{4}$ eutectic mixture takes place [2].

Physical properties change as the calcination of gypsum takes place. Some of the most apparent modifications are the reduction in strength, heat capacity and volume.

The goal of this project was to evaluate the fire resistive properties of the nine generic gypsum wallboard groups. Tests were conducted to determine the potential heat, rate of heat release, ease of ignition, and rate of flame spread of these gypsum materials so that their fire resistive properties may be better understood. These properties were chosen because they provide a broad base for additional analysis of the materials and lead to a better understanding of how the materials may react in a fire situation. A scanning electron microscope was used to examine the effect of fire on the modified gypsum core of $13 \mathrm{~mm}$ ( $1 / 2 \mathrm{in}$ ) type-X gypsum board. A discussion of these property tests and the microscopic investigation follows:

\subsection{Potential Heat}

The objective of the potential heat test is to provide a reasonable estimate of the total amount of heat which could be released during a building fire. Information concerning potential heat enables certain regulatory groups to control materials used in building construction based on the quantity of heat or "fuel" contribution.

The potential heat of a material may be defined as the difference between (a) the heat of combustion of a representative sample of material and (b) the heat of combustion of the residue remaining after exposure to a simulated standard fire using combustion calorimetric techniques [3]. The potential heat of a material is a major indicator that can be used to determine the extent to which a building material may contribute heat to support active combustion during a fire. The value of this property is of great importance in the design of a building and specification of materials and furnishings to be used in the structure.

\subsection{Rate of Heat Release}

In addition to the total available heat, the rate at which a burning material releases heat plays a major role in the growth of a fire. In a room fire, a large portion of the heat released collects in the upper portion of the room and may be absorbed by the walls and ceiling. The attendant rise in air and 
surface temperature creates thermal radiation levels which serve to produce new ignitions, increase flame spread, and further increase the rate of heat release of the building materials and furnishings. Therefore, the rate of fire buildup in a room depends on the rate of heat release of the room contents and construction materials [4].

\subsection{Ease of Ignition}

The ease with which a material ignites by flame contact is another property which may also influence fire buildup. For example, if a fire develops in a waste paper basket, the objects around it may be impinged upon by the flame. If the adjacent materials ignite rapidly, the fire will quickly grow larger. However, if the ignition time for a material is longer than the duration of the fire in the waste basket, the fire will die out.

\subsection{Flame spread}

The rate and extent to which flames travel across the surface of a material is controlled by the properties of the material and the environment around the involved area. The important properties of a material are its thermochemical and thermophysical properties, thickness, and orientation. The environmental factors which may influence the flame spread rate are the level of incident thermal radiation, temperature, air movement and oxygen concentration.

Flame spread tests are designed for the determination of flame spread rates and distances over a surface of a material while it is exposed to a standardized fire environment. The tests also attempt to classify the material and assign a flame spread index number which reflects the rate or distance of flame spread over the surface.

\subsection{Material Examination by Scanning Electron Microscope}

\section{3-mm (1/2-in) Type-X Gypsum Board}

Because gypsum board changes significantly during the exposure to fire, it was felt that a microscopic analysis of the burned gypsum core would be useful in improving the understanding of this degradation process.

It is known that gypsum contains chemically bound water and that it can be removed by applying heat. The application of heat results in the calcination of the gypsum and the reduction of physical strength. The type-x board contains other materials which are introduced into the board core to provide a means of maintaining strength and stability during prolonged fire exposures. Two of the components usually added to the core are vermiculite and short strands of fiber glass. An objective of this microscopic observation was to view any changes which take place in the core as a result of it being exposed to fire.

\section{TEST SPECIMENS}

Nine gypsum board products were selected for test in this project. The materials are currently used in typical residential and commercial structures. These materials are manufactured by all of the major producers of gypsum board products, and are considered to be generic by the Model Building Codes. 
The products chosen for this study were selected at random from typical production and supplied by four manufacturers. The following is a list of the materials studied:

$8 \mathrm{~mm}(5 / 16$ in) $\mathrm{MH}$ Gypsum Board

$13 \mathrm{~mm}(1 / 2 \mathrm{in)}$ Regular Gypsum Board

$13 \mathrm{~mm}(1 / 2 \mathrm{in})$ Gypsum Formboard

$13 \mathrm{~mm}(1 / 2 \mathrm{in})$ Regular Gypsum Board with $.2 \mathrm{~mm}$

(.008 in) Vinyl Coating

$13 \mathrm{~mm}(1 / 2$ in) Gypsum Sheathing

$13 \mathrm{~mm}(1 / 2 \mathrm{in)}$ Water Resistant Gypsum Backer Board

$13 \mathrm{~mm}$ ( $1 / 2 \mathrm{in)}$ Type- $\mathrm{x}$ Gypsum Board

$16 \mathrm{~mm}$ ( $5 / 8 \mathrm{in)}$ Type-X Gypsum Board

$25 \mathrm{~mm}$ ( 1 in) Gypsum Core Board

A description of each material and use follows:

$8 \mathrm{~mm}$ (5/16 in) MH Gypsum Board - This board is designed for use in mobile home construction with or without further surface decoration. Its composition is essentially a reinforced noncombustible gypsum core. 3 Glass fiber is generally used for reinforcement. The core is incased in paper. It meets the requirements of ASTM C36-76A Standard Specification for Gypsum Wallboard and Glass Fiber Reinforcement not exceeding 15 weight percent of the core.

$13 \mathrm{~mm}$ (1/2 in) Regular Gypsum Board - This board is designed to be used for the surface layer on interior walls and ceilings that provide a smooth even surface suitable for decoration. Its composition is a noncombustible gypsum core with paper on the face, sides and back of the board. It meets requirements of ASTM C36-76A standard specification for Gypsum Wallboard.

$13 \mathrm{~mm}$ (1/2 in) Gypsum Formboard - This is used as a support and permanent form to hold gypsum concrete in poured gypsum roof decks. The material consists of a noncombustible gypsum core, with or without fiber. The surface is covered with sheets of fibrous materials, usually paper. The exposed surface is chemically treated to resist fungus growth. It meets the requirements of ASTM C318-67 Standard Specification for Gypsum Formboard.

$13 \mathrm{~mm}(1 / 2 \mathrm{in}) .2 \mathrm{~mm}$ (.008 in) Vinyl Gypsum Board - This material is regular gypsum board that has been predecorated with $.2 \mathrm{~mm}$ (.008 in) vinyl. It meets the requirements of ASTM C36-76A.

$13 \mathrm{~mm}$ (1/2 in) Gypsum Sheathing - This is used to stiffen exterior frame walls against the forces of wind and vibration and to provide fire resistance. Sheathing is covered with an exterior finish, such as siding. Sheathing board consists of a noncombustible core, essentially gypsum with or without fiber. The core is treated with water-repellent chemicals and the surface is covered with a water-repellent paper. It meets the requirements of ASTM C79-67(73) specification for Gypsum sheathing Board.

3 The basic gypsum board core is considered to be noncombustible on the basis of ASTM E 136-73 Noncombustibility of Elementary Materials test results. 
$13 \mathrm{~mm}(1 / 2 \mathrm{in})$ Water-Resistant Gypsum Backer Board - This product serves as a base for the application of wall tile in baths, showers, and other wet areas. It consists of a waterresistant gypsum core, with or without fiber or aggregates. The surface is covered with water-resistant paper bonded to the core. It meets the requirements of ASTM C630-74A Specification for Water-Resistant Gypsum Backing Board.

$13 \mathrm{~mm}$ (1/2 in) Type-X Gypsum Board - This material is similar in all respects to regular gypsum board except that the core is made more fire resistant by the addition of glass fiber reinforcement and other materials. This product is designed to provide a 3/4-hour fire rating in the ASTM E 119 Fire Endurance Test when used in the construction of a specified wall assembly [5]. It meets the requirements of ASTM C36-76A and contains glass fiber reinforcement not exceeding 15 weight percent of the core.

$16 \mathrm{~mm}$ (5/8 in) Type-X Gypsum Board - This material is similar in all respects to $13 \mathrm{~mm}$ (1/2 in) regular gypsum board except that the core is thicker and is made more fire resistant by the addition of glass fiber reinforcement and other materials. This product is designed to provide a one-hour fire rating in the ASTM E 119 Fire Endurance Test when used in the construction of a specified wall assembly [5]. It meets the requirements of ASTM C36-76A and contains glass fiber reinforcement not exceeding 15 weight percent of the core.

$25 \mathrm{~mm}$ (l in) Gypsum Core Board - It is used as a wall base, as a self-supporting gypsum wall errected without framing, and in demountable walls. It consists of a noncombustible core, essentially gypsum, with and without fiber. A paper surface is bonded to the core. It meets the requirements of ASTM 442-72 Specification for Gypsum Backing Board.

\subsection{Sampling and Conditioning}

In all cases except one, specimens were taken from the center third of 1.2 by $2.4 \mathrm{~m} \mathrm{(} 4$ by $8 \mathrm{ft}$ ) board products. The specimens taken from core board came from the center third of a board measuring 0.6 by 1.2 ( 2 by $4 \mathrm{ft}$ ). Specimens were cut to the various dimensions specified by the appropriate test. All specimens were cut with their long dimension parallel to the paper grain of the gypsum board. The specimens were then conditioned in an atmosphere of 508 relative humidity at $23.8^{\circ} \mathrm{C}\left(73^{\circ} \mathrm{F}\right)$ until they reached weight equilibrium. When test methods required special conditioning, the test specimens were subjected to the conditions specified. No finishes were applied to the surface of the samples; however, it should be noted that the $13 \mathrm{~mm}(1 / 2 \mathrm{in})$ vinyl gypsum board is a factory finished product.

\subsection{Specimen Preparation for the Potential Heat Test}

The specimens prepared for the potential heat test were handled in the following way:

Representative rectangular samples of known area $968 \mathrm{~mm}^{2}$ (1.5 in ${ }^{2}$ ) were taken from the field of the various gypsum board products. The face and back paper was removed by cutting the paper away from the core and ground with a mechanical mill until all material passed through a 60 mesh sieve screen. Care was taken to prevent segregation. The board core material was then ground by hand using a mortar and pestle until it also passed through the 60 
mesh screen. Special care was taken to insure that calcination of the gypsum did not occur during the grinding process. The core and paper corresponding to the original sample area was then combined and thoroughly blended. The specimen was then exposed to a $50 \%$ relative humidity $23.8{ }^{\circ} \mathrm{C}\left(73{ }^{\circ} \mathrm{F}\right)$ atmosphere until it reached weight equilibrium. This method of specimen preparation was used on all of the standard tests conducted; however, two special potential heat tests were conducted on 13-mm (1/2-in) regular gypsum board. The specimens for these tests were prepared as follows:

The requirements for the first of the two additional tests performed stated that the core material, face, and back paper be tested as individual units. The face and back papers were tested in their original state as shipped from the paper mill. These samples did not come into contact with the gypsum board core at any time. The potential heat of the gypsum board core was also ascertained as an individual item.

The second set of special tests required that a specimen be taken from the 13-mm (1/2-in) regular gypsum board in the following manner. A specimen was removed from the board that consisted of a 3-mm (1/8-in) thick section of core with the face paper attached, and then it was ground into the minus 60 mesh homogeneous powder. The potential heat test was performed on this composite. A core/back paper specimen of the same geometry was also prepared and tested.

\subsection{Specimen Preparation for the Scanning Electron Microscope Observations}

A $13-\mathrm{mm}(1 / 2-i n)$ by $76-\mathrm{mm}$ (3-in) specimen was removed from a 13-mm (1/2in) type-x gypsum board. The specimen was cut in half and one-half of the sample was fired in a muffle furnace for one hour at $750{ }^{\circ} \mathrm{C}\left(1382^{\circ} \mathrm{F}\right)$. The specimen was then removed from the furnace and cooled to room temperature in a desiccator.

The second half of the original sample was handled in the following way. It was not exposed to any fire condition; however, the face and back paper was removed so the core could be directly viewed.

Representative samples were then taken from these two materials, mounted on specimen stubs, and sputter coated with .01 microns ( $100 \AA)$ of gold. The specimens were then viewed with a commercial scanning electron microscope (SEM).

\section{TEST APPARATUS AND PROCEDURES}

\subsection{Standard Test Method for Potential Heat of Building Materials- \\ NFPA Standard 259-1976}

Two samples are removed from the material to be tested. One is pulverized, pelleted, and then burned in an oxygen bomb calorimeter. This yields a measure of the gross heat of combustion of the material. In the case of materials of low combustible content, a combustion promoter is added prior to pelleting the specimen for test in the combustion calorimeter.

The second specimen of approximately 13 by 19 by $76 \mathrm{~mm}(1 / 2$ by $3 / 4$ by 3 in) size is "fired" in a muffle furnace. The firing of the specimen is accomplished by heating it in air for two hours at a temperature of $7500^{\circ} \mathrm{C}$. The weight loss of the specimen is noted, and the residue remaining, if it is more than five percent of the original weight, is pulverized into a homogeneous powder. A portion of the resulting powder is mixed with a corresponding weight of combustion promoter, pelleted, and burned in the combustion 
calorimeter as previously described. After correcting for the heat produced by the combustion promoter, the difference in heating values of the two specimens is reported as the potential heat [6].

See figure 1 for the flow diagram of the test method which illustrates the steps involved [3].

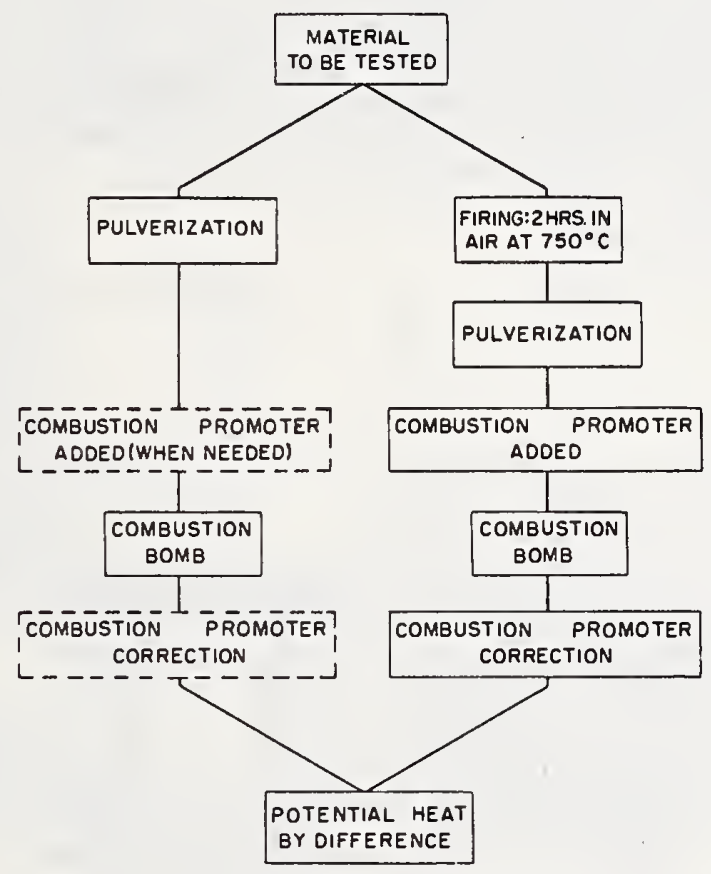

Figure 1. Schematic Diagram of Test Procedure for Potential Heat Measurements

\subsection{Test for Measuring the Rate of Heat Release of Building Materials - NBS Method}

The National Bureau of Standards rate of heat release calorimeter [4] consists of three chambers which are classified as follows: (1) Combustion Chamber; (2) Control Chamber; and (3) Mixing Chamber.

The tests conducted for this study were run with thermal radiation levels of $6 \mathrm{~W} / \mathrm{cm}^{2}$ and $4 \mathrm{~W} / \mathrm{cm}^{2}$. The $4 \mathrm{~W} / \mathrm{cm}^{2}$ exposure required the use of a gas pilot flame for ignition of the gypsum board paper; with the $6 \mathrm{~W} / \mathrm{cm}^{2}$ exposure the paper ignited rapidly without a pilot flame.

After the calorimeter has been stabilized and calibrated, a 115 by $152 \mathrm{~mm}$ ( 4.5 by $6 \mathrm{in}$ ) specimen is placed in a vertically oriented holder which is located at the center of the combustion chamber. Only the specimens finished surface is exposed to radiation from the radiant panels which are located on three sides of the combustion chamber. The edges of the specimen are shielded by the insulated holder, and the rear surface is separated from a water-cooled brass block by an approximate 13-mm (1/2-in) air space. 
The air space behind the specimen represents a small section of wall cavity. The heat transferred from the rear surface of the specimen to the brass block is measured by a thermocouple which registers the rate of temperature rise of the cooling water circulating through the block.

A propane burner located inside the control chamber of the calorimeter produces heat at a considerably greater rate than that of the burning specimen. As the specimen burns, the propane flow is automatically reduced by the amount necessary to maintain the flue gas in the mixing chamber at a constant temperature. The rate of heat release through the front surface of the specimen is determined from the reduction in propane flow. Only the heat released at the front surface of the specimen is stated in this report. A drawing of the calorimeter is located in figure [4]

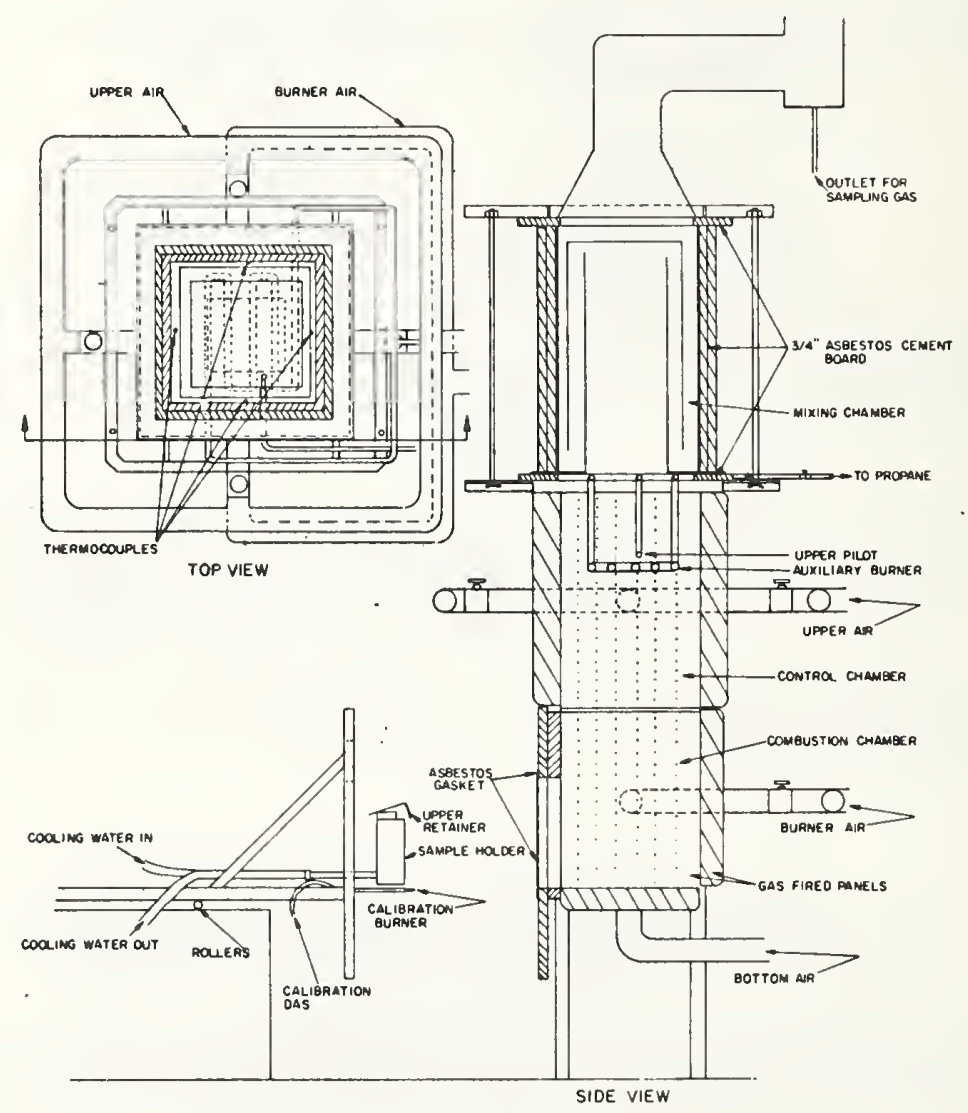

Figure 2. NBS Heat Release Rate Calorimeter

\subsection{Ease of Ignition by Flame Impingement Test Method}

An ease of ignition by flame impingement test method, recently developed at NBS, was used to evaluate the ignition characteristics of the gypsum board products (see fig. 3). 

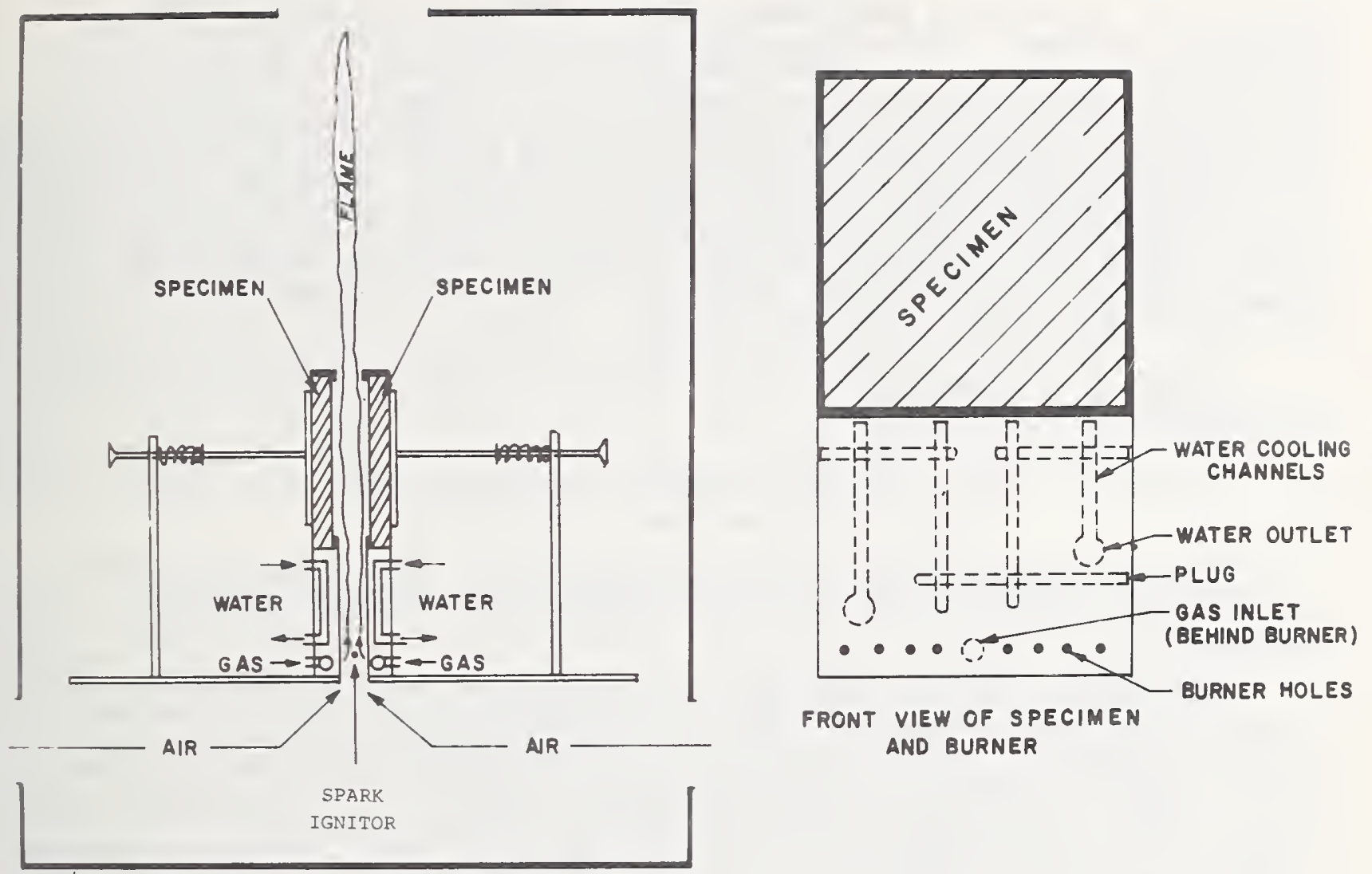

FRONT VIEW OF APPARATUS

Figure 3. Sketch of Ignition Apparatus

The test apparatus consists of two specimen holders $140 \mathrm{~mm}(5-1 / 2 \mathrm{in})$ wide and $152 \mathrm{~mm}$ ( 6 in) high that position the specimens $50 \mathrm{~mm}$ (2 in) apart. The burner is constructed out of two brass blocks that are water-cooled, and they support the specimen holders located on top. The brass blocks are positioned vertically and on the same plane as the specimen holders. A horizontal row of $2 \mathrm{~mm}$ (1/16 in) holes spaced $13 \mathrm{~mm}$ (1/2 in) apart located near the bottom of the brass blocks allows methane gas to pass into the opening between the blocks and specimens. The gas is ignited by an electrical spark ignition system located near the gas ports. The exposure flame develops rapidly and passes between the two specimen surfaces and extends about $152 \mathrm{~mm}$ ( 6 in) above the test frame. Almost $3 / 4$ of the specimen's surface is impinged upon by this flame and ignition of many organic materials generally occurs as a result of this exposure. The average incident heat flux, radiant and convective, on the specimen surface is about $3.3 \mathrm{~W} / \mathrm{cm}^{2}$.

The test begins by mounting two identical samples in the specimen test frames. A dual pen chart recorder is started. The recorder receives an output from a photo tube which views the specimens and records the amount of light emitted as the test material contributes energy to the exposure flame. The second channel of the recorder is connected to a push button actuated time marker circuit for observations made by the operator. The electrical spark igniter is turned on, and the solenoid gas control valves are opened. The exposure flame develops between the specimens, and 
observations are made by the operator and marked on the recorder chart throughout the test. The following events are logged during the test: time of surface degradation, ignition time, contribution time, and time of flame persistance. The time of surface degradation is determined by observing the specimen and recording the time at which visible changes are noticed. Ignition is considered to be the time of flame attachment to the surface. The contribution time is determined by a 25 percent rise in light output of the photo tube and indicates when the specimen is contributing to flame intensity. The time of flame persistance is determined by cutting off the exposure flame when it appears that the specimen will sustain a flame without external support. The flame persistance time is the difference between exposure flame cut off the end of self sustained flaming.

Six tests were conducted using the above procedure to provide an average ignition time and replication.

\subsection{Surface Flammability of Materials \\ Using a Radiant Panel (ASTM E 162)}

The test apparatus used in this method consists of a radiant panel, a frame to support the test specimen, and associated measuring equipment (see fig. 4).

The radiant panel consists of a cast iron frame enclosing a 305-by 457-mm (12-by 18-in) porous refractory material. The panel is mounted in a vertical plane and a premixed gas-air mixture supplied from the rear is burned in intimate contact with the refractory surface, providing a radiant heat source. The energy output of the panel equals that obtained from a black body of the same dimensions operating at a temperature of $670^{\circ} \mathrm{C}$ $\left(1264^{\circ} \mathrm{F}\right)$. A stack placed under the vent hood above the test specimen receives the hot products of combustion and smoke. The heat liberated by the specimen is measured at this location by a group of thermocouples.

The test specimen, measuring 152 by $457 \mathrm{~mm}$ ( 6 by $18 \mathrm{in}$ ) is dried for 24 hours at $60^{\circ} \mathrm{C}\left(140{ }^{\circ} \mathrm{F}\right)$, and then conditioned to equilibrium at an ambient temperature of $23+3^{\circ} \mathrm{C}\left(73+5{ }^{\circ} \mathrm{F}\right)$ and a relative humidity of $50 \pm 5$ percent. It is then placed in the metaI holder and hung on the test frame. The orientation of the specimen is such that ignition is forced near its upper edge by the gas pilot, and the flame front progresses downward.

A factor derived from the rate of progress of the flame front (ignition properties) and another relating to the rate of heat liberated by the material under test are combined to provide a flame spread index $[7,8]$.

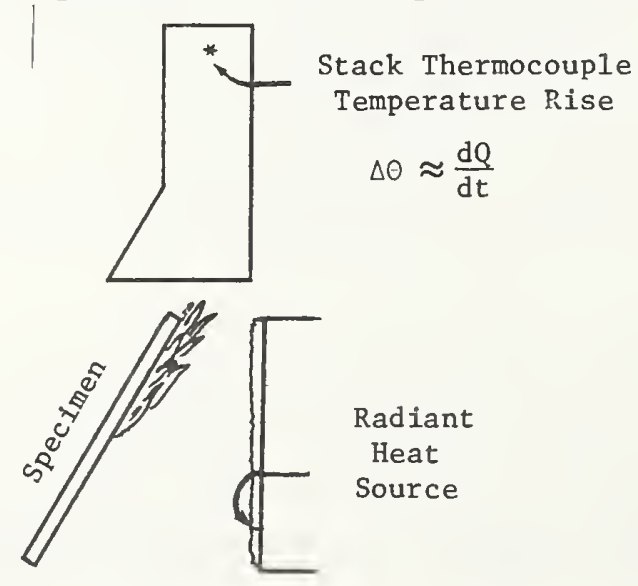

Figure 4. Diagrammatic Drawing of a RadiantPanel Test Method 


\section{TEST RESULTS AND DISCUSSION}

\subsection{Potential Heat Test}

A total of seventeen tests were conducted during this test program. Single determinations were made on six (6) of the nine (9) materials. 2wo determinations were made on three (3) of the materials in order to check the repeatability of the test results. A special set of tests involving seven (7) determinations on board components was also conducted on $13-\mathrm{mm}(1 / 2-i n)$ regular gypsum board. This was done to determine if the testing of individual board components (paper and core) would actually yield the same results as obtained from the composite specimen. During this study, it was decided to also compair the weight of chemically bound water in the gypsum board core with its theoretical weight (21.08). The board core specimen after being calcined in the muffle furnace provided a favorable comparison with a weight loss of 20.68. A second objective was to check the feasibility of obtaining the values of each component and using them to calculate the potential heat value of other materials that contain the same components but in different proportions.

From the data listed in table 1, it can be seen that both of the special battery of tests performed on the components of the regular gypsum board compare favorably $(410$ vs 390$)$ to the test results obtained from the composite samples. This indicates that both methods of specimen preparation are reliable if good laboratory techniques are used. It also indicates that the second objective mentioned above is feasible when making the following assumptions. In order to calculate the potential heat of the various gypsum board products that occur in specific generic groups such as regular board, it must be assumed that the paper and board core formulations are relatively uniform. On this basis, the potential heat values can be calculated for boards of various thicknesses. Using the potential heat results developed on the components of 13-mm (1/2-in) regular gypsum board, potential heat values were calculated on three regular board products which varied in cross-sectional dimensions. These values have been included in table 1 . The component weight fractions used for the calculation of each of the three materials is located in the Appendix.

Some problems were experienced in performing the oxygen bomb test. These problems occurred while attempting to test the individual paper specimens. The test method requires that a one (1) gram pellet be formed for oxygen bomb firing. This procedure was followed in preparing the paper materials. However, it was found that the paper was very resilient and after being compressed as tightly as possible the pellet height was equal to the height of the test crucible sides. Upon igniting the specimen in the bomb, it became apparent that violent burning occurred which caused a portion of the specimen to be thrown from the crucible where it fell to the bottom of the bomb and was quenched. This action resulted in the lack of combustion of a large percentage of the specimen and this required the retesting of the sample material. A second test was run which ended with the same results. It was decided at this time to perform the test on a 0.5-gram specimen pellet. During this test, all of the specimen remained within the crucible and burned to completion. It was then found that the paper left a residue which was in excess of one percent. This finding required that a second oxygen bomb test be conducted using a 0.5 -gram paper sample blended with 0.5 grams of benzoic acid combustion promoter. This method of specimen preparation worked well and produced acceptable results with approximately the same amount of residue remaining.

As can be seen in table 1 , core board has the lowest potential heat value of all materials tested. This is attributed to an increase in the core to paper ratio. The influence of core to paper ratio is exhibited throughout the range of board thicknesses. 
Table 1. Gypsum Board Potential Heat Test Results ${ }^{\star \star}$ NFPA 259 Method

\begin{tabular}{|c|c|c|c|c|c|c|c|c|}
\hline \multirow[t]{2}{*}{ Material } & \multicolumn{2}{|c|}{$\begin{array}{l}\text { Specimen Yeat } \\
\text { of Combustion }\end{array}$} & \multicolumn{2}{|c|}{$\begin{array}{l}\text { Residue Heat } \\
\text { of Combustion }\end{array}$} & \multicolumn{4}{|c|}{ Potential Heat } \\
\hline & $\mathrm{J} / \mathrm{g}$ & Bt $u / 1 b$ & $\mathrm{~J} / \mathrm{g}$ & Btu/1b & $\mathrm{J} / \mathrm{g}$ & $\mathrm{J} / \mathrm{cm}^{2}$ & Btu/1b & $\mathrm{Btu} / \mathrm{ft}^{2}$ \\
\hline $6 \mathrm{~mm}\left(1 / 4^{\prime \prime}\right)$ Regular Board & \multicolumn{2}{|c|}{ Calculated } & & & 2230 & 9770 & $960^{*}$ & 860 \\
\hline $8 \mathrm{~mm}\left(5 / 16^{\prime \prime}\right)$ MH Board & 140 & 60 & -1900 & -817 & 1510 & 8860 & 650 & 780 \\
\hline $10 \mathrm{~mm}\left(3 / 8^{\prime \prime}\right)$ Regular Board & \multicolumn{2}{|c|}{ Calculated } & & & 1390 & 9200 & $600^{\star}$ & 810 \\
\hline $13 \mathrm{~mm}\left(1 / 2^{\prime \prime}\right)$ Formboard & $\begin{array}{l}12 \\
37\end{array}$ & $\begin{array}{r}5 \\
16\end{array}$ & $\begin{array}{l}-1710 \\
-1765\end{array}$ & $\begin{array}{l}-735 \\
-759\end{array}$ & $\begin{array}{l}1260 \\
1330\end{array}$ & $\begin{array}{l}12270 \\
12950\end{array}$ & $\begin{array}{l}540 \\
570\end{array}$ & $\begin{array}{l}1080 \\
1140\end{array}$ \\
\hline $13 \mathrm{~mm}\left(1 / 2^{\prime \prime}\right)$ Sheathing & 1214 & 522 & -1714 & -737 & 2440 & 23850 & 1050 & 2100 \\
\hline $\begin{array}{l}13 \mathrm{~mm}(1 / 2 ") \text { Water Re- } \\
\text { sistant Backer Board }\end{array}$ & 1772 & 762 & -1284 & -552 & 2670 & 24870 & 1150 & 2190 \\
\hline $13 \mathrm{~mm}\left(1 / 2^{\prime \prime}\right)$ Regular Board & $\begin{array}{l}-302 \\
-254\end{array}$ & $\begin{array}{l}-130 \\
-109\end{array}$ & $\begin{array}{l}-1610 \\
-1770\end{array}$ & $\begin{array}{l}-692 \\
-761\end{array}$ & $\begin{array}{r}910 \\
1070\end{array}$ & $\begin{array}{l}7950 \\
9430\end{array}$ & $\begin{array}{l}390 \\
460\end{array}$ & $\begin{array}{l}700 \\
830\end{array}$ \\
\hline $13 \mathrm{~mm}\left(1 / 2^{\prime \prime}\right)$ Type-X Board & -188 & -81 & -1710 & -735 & 1090 & 10110 & 470 & 890 \\
\hline $\begin{array}{l}13 \mathrm{~mm}\left(1 / 2^{" \prime}\right) \text { Vinyl Board } \\
0.2 \mathrm{~mm}\left(.008^{\prime \prime}\right) \text { Vinyl }\end{array}$ & -88 & -38 & -1677 & -721 & 1090 & $10 i 10$ & 470 & 890 \\
\hline $16 \mathrm{~mm}$ (5/8") Regular Board & \multicolumn{2}{|c|}{ Calculated } & & & 700 & 7720 & $300 *$ & 680 \\
\hline 16m (5/8") Type X-Board & $\begin{array}{l}-335 \\
-400\end{array}$ & $\begin{array}{l}-144 \\
-172\end{array}$ & $\begin{array}{l}-1200 \\
-1451\end{array}$ & $\begin{array}{l}-516 \\
-624\end{array}$ & $\begin{array}{l}560 \\
700\end{array}$ & $\begin{array}{l}6590 \\
8180\end{array}$ & $\begin{array}{l}240 \\
300\end{array}$ & $\begin{array}{l}580 \\
720\end{array}$ \\
\hline $25 \mathrm{~mm}$ (1") Core Board & -837 & -360 & -1779 & -765 & 510 & 10220 & 220 & 900 \\
\hline \multicolumn{9}{|l|}{ Spectal Tests } \\
\hline $13 \mathrm{~mm}(1 / 2 ")$ Regular Board & $\mathrm{Ca} 1$ & ed from & Component Values & & 950 & 8400 & $410 *$ & 740 \\
\hline Face Paper & 17000 & 7300 & - & -- & 17000 & 5220 & 7300 & 460 \\
\hline Back Paper & 18000 & 7700 & - & -- & 17900 & 5790 & 7700 & 510 \\
\hline Core & -1784 & -767 & -1845 & -793 & -330 & -2610 & -140 & -230 \\
\hline $13 \mathrm{~mm}\left(1 / 2^{\prime \prime}\right)$ Regular Board & & & & & 910 & 7950 & $390 *$ & 700 \\
\hline \multicolumn{9}{|l|}{$\begin{aligned} 3 \mathrm{~mm}\left(1 / 8^{\prime \prime}\right) & \begin{array}{l}\text { Core/Paper } \\
\text { Sect Ions }\end{array}\end{aligned}$} \\
\hline Core/Face Paper & 942 & 405 & -1796 & -772 & 2190 & 4770 & 940 & 420 \\
\hline Core/Back Paper & 889 & 382 & -1731 & -744 & 2090 & 4540 & 900 & 400 \\
\hline
\end{tabular}

* Calculated values on basis of estimated board welghts and results of $13 \mathrm{~mm}\left(1 / 2^{\prime \prime}\right)$ regular board core and paper components.

${ }^{* *}$ Results 1 isted are not average but are single determinations.

Because this test method is relatively sensitive to sampling procedure, specimen preparation, and laboratory technique, special care was taken to stay within the recommended reproducibility limits. Duplicate measurements of potential heat are expected to agree within $460 \mathrm{~J} / \mathrm{g}(200 \mathrm{Btu} / \mathrm{lb})$ in the same laboratory and within $1160 \mathrm{~J} / \mathrm{g}(500 \mathrm{Btu} / \mathrm{lb})$ at different laboratories [9]. In this study, duplicate tests were conducted on gypsum formboard, $13 \mathrm{~mm}$ (1/2") regular board, and $16 \mathrm{~mm}$ (5/8") type-X board. The results of these tests indicate a reproducibility of less than $175 \mathrm{~J} / \mathrm{g}(75 \mathrm{Btu} / \mathrm{lb})$. 


\subsection{Rate of Heat Release}

Three sets of tests were conducted on the nine gypsum board materials using the NBS Rate of Heat Release Calorimeter. This was done in order to obtain an indication of how the materials would react in various radiant flux environments. There were two sets tested with an exposure of $4 \mathrm{~W} / \mathrm{cm}^{2}$ (see table 2), one with a pilot flame above the specimen and one without. Only the vinyl board exhibited a flaming ignition when tested without the pilot flame. When the pilot was present, all of the materials exhibited a flaming ignition except one type-X board specimen and two core board specimens. However, the 25-mm (1-in) core board had a flaming ignition on only one of the three specimens tested. All of the samples exposed at the $6 \mathrm{~W} / \mathrm{cm}^{2}$ radiant energy level ignited and exhibited flaming.

Generally, all of the gypsum board products performed within a narrow peak heat release range on the battery of tests conducted. It was observed however, that a few of the specimens did vary somewhat from the norm. The only material which showed a significantly higher heat release compared to the others was the $13-\mathrm{mm}(1 / 2-i n)$ vinyl covered gypsum board. This is most apparent in the unpiloted $4 \mathrm{~W} / \mathrm{cm}^{2}$ and $6 \mathrm{~W} / \mathrm{cm}^{2}$ exposures. The higher heat release during the unpiloted $4 \mathrm{~W} / \mathrm{cm}^{2}$ test is attributed to the ignition of the vinyl finish.

The peak release rate of the unpiloted $4 \mathrm{~W} / \mathrm{cm}^{2}$ test resulted in the greatest degree of variation with a range of within $\pm 25 \%$ between all materials tested except the vinyl which exhibited flaming. The type-x board products had low peak heat release rates at $6 \mathrm{~W} / \mathrm{cm}^{2}$. However, the peak was reached earlier as compared to the $4 \mathrm{~W} / \mathrm{cm}^{2}$ exposure. The reduction in heat release at $6 \mathrm{~W} / \mathrm{cm}^{2}$ was probably due to the absence of the pilot flame. Another point of interest which is seen in table 2 is that the percent weight loss was approximately the same in each test series on all of the materials tested. This resulted from the chemically combined water in the gypsum board core being removed at a controlled rate which is established by the total heat flux interacting with the specimen.

\subsection{Ease of Ignition}

Six individual tests were conducted on each of the nine materials. Data from these tests are included in table 3. The time of degradation relates to the time that the first signs of surface change or discoloration occurs on the specimen. All of the recorded times, except the one on $13 \mathrm{~mm}$ ( $1 / 2 \mathrm{in}$ ) vinyl covered gypsum board, relate to the browning or charring of the paper exposed to the test flame. The vinyl covered board exhibited the development of small bubbles before charring occurred and the time of degradation was taken from the time the first bubbles were observed.

Ignition is determined by observing the specimen during the flame exposure period and marking the chart record when flame attachment occurs. The flame exposure time required to obtain flame attachment to the specimen is cataloged as the ignition time (see table 3 ). The average ignition times on the basis of six determinations of the materials tested, varied from a minimum of 27 seconds for vinyl covered gypsum board to a maximum of 83 seconds for gypsum formboard and water resistant backer board. The average ignition time for regular board was 50 seconds. 


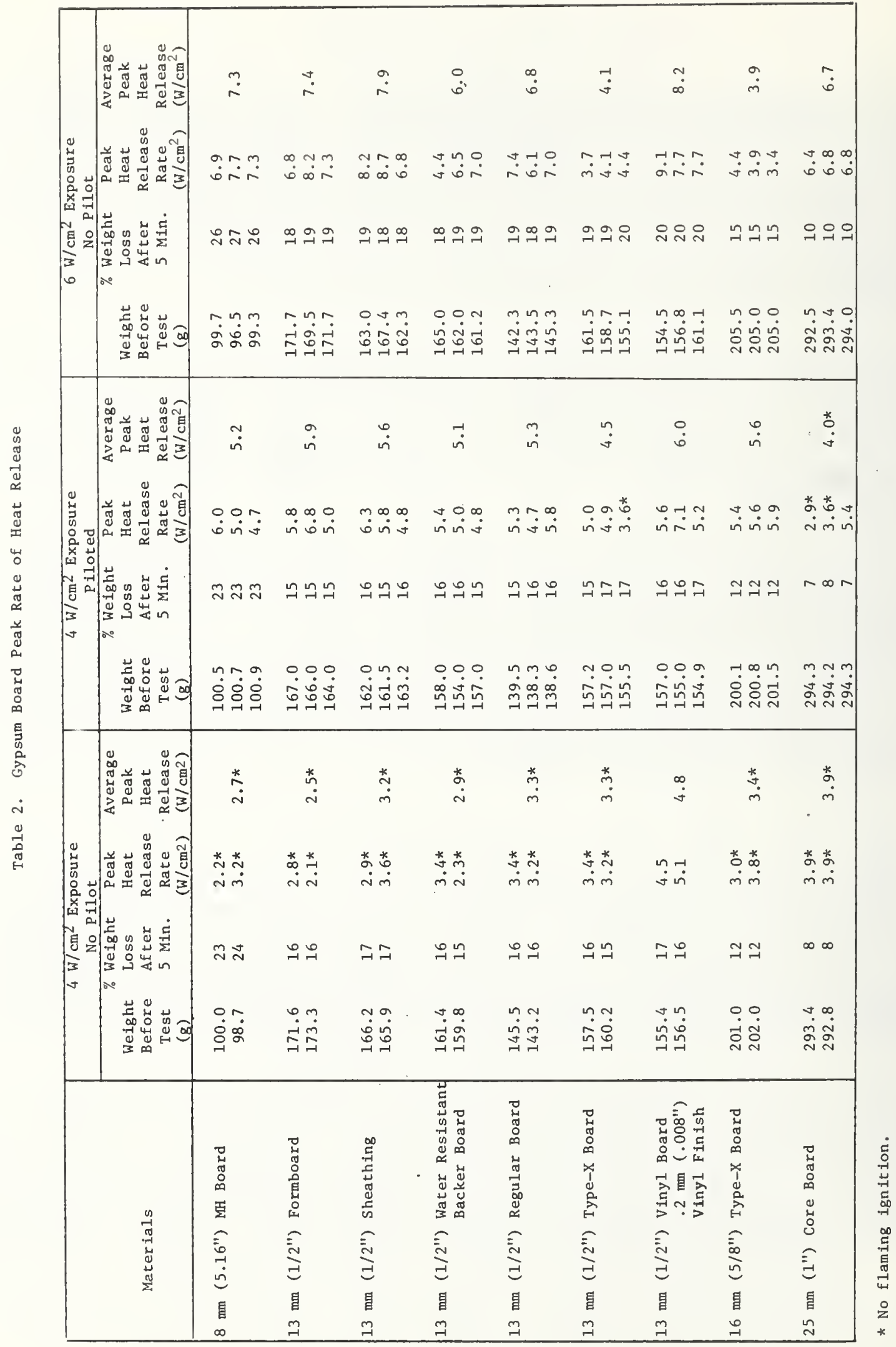


Table 3. Gypsum Board Ease of Ignition Test Results *

\begin{tabular}{|c|c|c|c|c|}
\hline Material & $\begin{array}{l}\text { Average } \\
\text { Surface } \\
\text { Degradation } \\
\text { Time (s) }\end{array}$ & $\begin{array}{l}\text { Average } \\
\text { Time of } \\
\text { Ignition } \\
\quad(\mathrm{s})\end{array}$ & $\begin{array}{l}\text { Minimum Exposure } \\
\text { Time Required for } \\
\text { Sustained Flaming } \\
\text { (s) }\end{array}$ & $\begin{array}{l}\text { Period of } \\
\text { Sustained } \\
\text { Flaming } \\
\quad(s)\end{array}$ \\
\hline $\begin{array}{l}8 \text { (5/16") } \\
M H \text { Board }\end{array}$ & 22 & 74 & 120 & 78 \\
\hline $\begin{array}{l}13 \mathrm{~mm}(1 / 2 " \\
\text { Formboard }\end{array}$ & 22 & 83 & 143 & 19 \\
\hline $\begin{array}{l}13 \text { (1/2" } \\
\text { Sheathing }\end{array}$ & 37 & 82 & 171 & 13 \\
\hline $\begin{array}{l}13 \text { ( } 1 / 2^{\prime \prime} \\
\text { Water Resistant } \\
\text { Backer Board }\end{array}$ & 18 & 83 & 125 & 19 \\
\hline $\begin{array}{l}13 \text { '(1/2") } \\
\text { Regular Board }\end{array}$ & 14 & 50 & 78 & 43 \\
\hline $\begin{array}{l}13 \mathrm{~mm}\left(1 / 2^{\prime \prime}\right) \\
\text { Type-X Board }\end{array}$ & 15 & 61 & 117 & 19 \\
\hline $\begin{array}{l}13 \mathrm{~mm}\left(1 / 2^{\prime \prime}\right. \\
\text { Vinyl Covered Board } \\
.2 \mathrm{~mm}\left(.008^{\prime \prime}\right) \text { Vinyl }\end{array}$ & 6 & 27 & 42 & 80 \\
\hline $\begin{array}{l}16 \mathrm{~mm}\left(5 / 8^{\prime \prime}\right) \\
\text { Type-X Board }\end{array}$ & 16 & 60 & 128 & 26 \\
\hline $\begin{array}{l}25 \text { ( } 1 ") \\
\text { Core Board }\end{array}$ & 40 & 71 & 102 & 3 \\
\hline
\end{tabular}

The average values shown were developed on the basis of six determinations.

The time of contribution is normally recorded as part of this test procedure; however, during this test series the gypsum board products did not contribute sufficiently to cause an increase in the photo tube output. Because the low contribution level did not provide any comparative information about the materials, it was decided to test for sustained flaming characteristics. This was accomplished by observing the specimen after flame attachment occurred. The exposure flame was allowed to continue and was shut off at random intervals when it appeared that the specimen would sustain a flame without external support. The flame persistance time was measured and the average from six determinations is listed in the table. The flame persistance time provides some information about how long a material will sustain flaming after the primary ignition flame is removed.

A review of the various test results indicated that there is a correlation between the average ignition times from the ease of ignition test and the average heat contribution times obtained from the rate of heat release calorimeter with the piloted $4 \mathrm{~W} / \mathrm{cm}^{2}$ exposure. Eight (8) of the nine (9) materials $(89 \%)$ tested had ignition times within 20 percent of the contribution times experienced with the calorimeter. Six (6) out of the nine (9) materials $(66 \%)$ had ignition and combustion times that differ less than 10 percent (see fig. 5). 
Ignition

(Ignition

Test)

Seconds

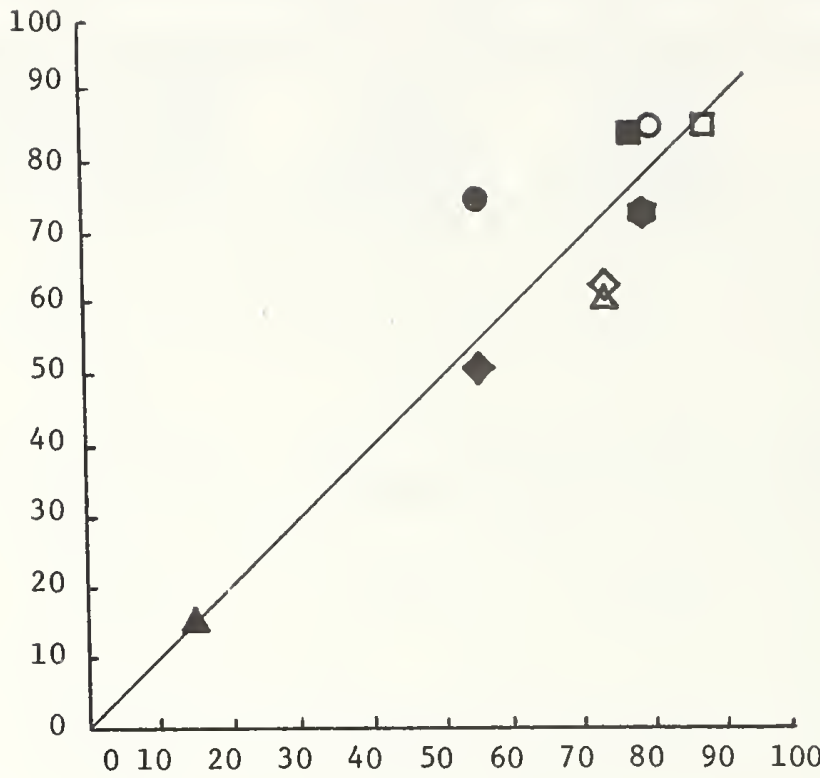

Heat Contribution

(Calorimeter)

Seconds

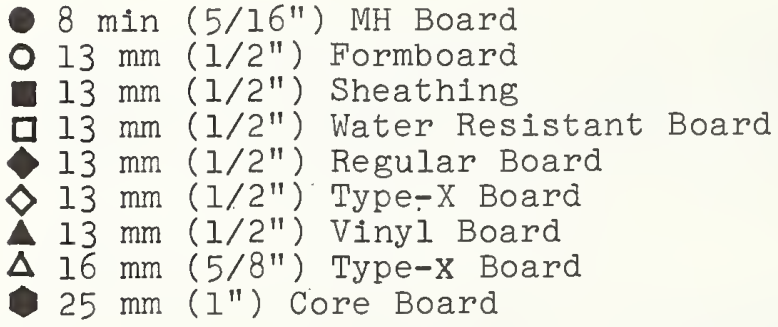

Figure 5. Average Ignition Time (Ignition Test) vs. Heat

Contribution Time Piloted $4 \mathrm{~W} / \mathrm{cm}^{2}$ Exposure (Calorimeter)

The time it takes sustained ignition to occur is recorded to indicate the point at which a material will support a self-sustaining flame. As mentioned earlier, sustained ignition is defined as having occurred if a flame persists any place on the specimen three seconds after the gas has been cut off. As can be seen in table 3, vinyl covered gypsum board exhibited the earliest ignition time of 42 seconds. The longest period of exposure for obtaining ignition was experienced by gypsum sheathing with a time of 171 seconds.

The sustained flaming times which indicate the burning time after the exposure flame is removed are also listed. Transient ignitions also occurred and are considered to be any flaming that remains on the surface of a specimen for periods of less than three seconds. 


\subsection{Flame spread}

Most of the materials tested using the ASTM E 162 method exhibited uniform burning characteristics. Four determinations were made on each material; the results are presented in table 4. Three specific materials tested showed a significant variation from the burning characteristics experienced with the other materials. These materials were $13 \mathrm{~mm}(1 / 2 \mathrm{in})$ gypsum sheathing, $13 \mathrm{~mm}$ (1/2 in) water resistant gypsum backer board and 13 $\mathrm{mm}(1 / 2$ in) vinyl covered gypsum board.

The tests reported show that gypsum sheathing and water resistant gypsum backer board had samples which resulted in a fairly short distance of flame travel as compared to the other specimens. Both of these materials had a water resistant treated core and paper. It is believed from the observations made that the paper and core treatment had an influence on the surface flame spread. Each of the specimens exhibited a gas phase flash ignition at the top, and the paper burned at a slow rate until the flame went out. A glowing ignition of the paper was apparent for several minutes after the flame died. When these materials were retested, a similar form of burning was experienced.

It is also apparent in table 4 that the vinyl covered gypsum board had the highest flame spread index number of all of the materials tested. However, the flame distance traveled and time was approximately equal to the distance traveled and time on the unfinished paper surfaces. The higher index number can be attributed to the burning of the vinyl which resulted in a significantly higher stack temperature. The average net stack temperature rise for the $13 \mathrm{~mm}(1 / 2 \mathrm{in})$ regular gypsum was $18.3{ }^{\circ} \mathrm{C}$, whereas the average net stack temperature rise for the vinyl finished board was $36.16^{\circ} \mathrm{C}$. The vinyl finish thus resulted in an approximate increase of $100 \%$ in heat release over the regular unfinished board.

Standard ASTM E 84 tests were conducted on the same generic materials (but not the same batch) addressed by this report during the past years as the materials were marketed. These tests were conducted at underwriters' Laboratories, Inc. and the test results have been included in table 4 to show the flame spread characteristics of the specimen as it relates to the $\mathrm{E} 84$ test method. The UL test report numbers are also included in table 4 for reference. The average E 162 flame spread index varied considerably on several of the materials as compared to the results obtained on the $E 4$. There is a limited correlation between the results. This can be seen in figure 6 and can also be observed in Underwriters' Laboratory Report "Flammability Studies of Cellular Plastics and Other Building Materials used for Interior Finishes." The E 162 test method was designed as a research tool and is not currently used by the model codes as a means of classifying building materials for code purposes.

Another point of interest is that the majority of the specimens tested exhibited a flame travel distance of between $254 \mathrm{~mm}$ (10 in) and $356 \mathrm{~mm}$ (14 in) in the E 162 test before the flame went out. This would indicate that the approximate heat flux from the radiant panel at the flame out point for these gypsum board products ranged between $1.58 \mathrm{~W} / \mathrm{cm}^{2}$ and $.90 \mathrm{~W} / \mathrm{cm}^{2}$ as determined from the energy flux per unit area profile given in the paper by Robertson, Gross, and Loftus entitled "A Method for Measuring Surface Flammability of Materials Using a Radiant Energy Source." The values given in the table are based on interpolation of data from the above report. 


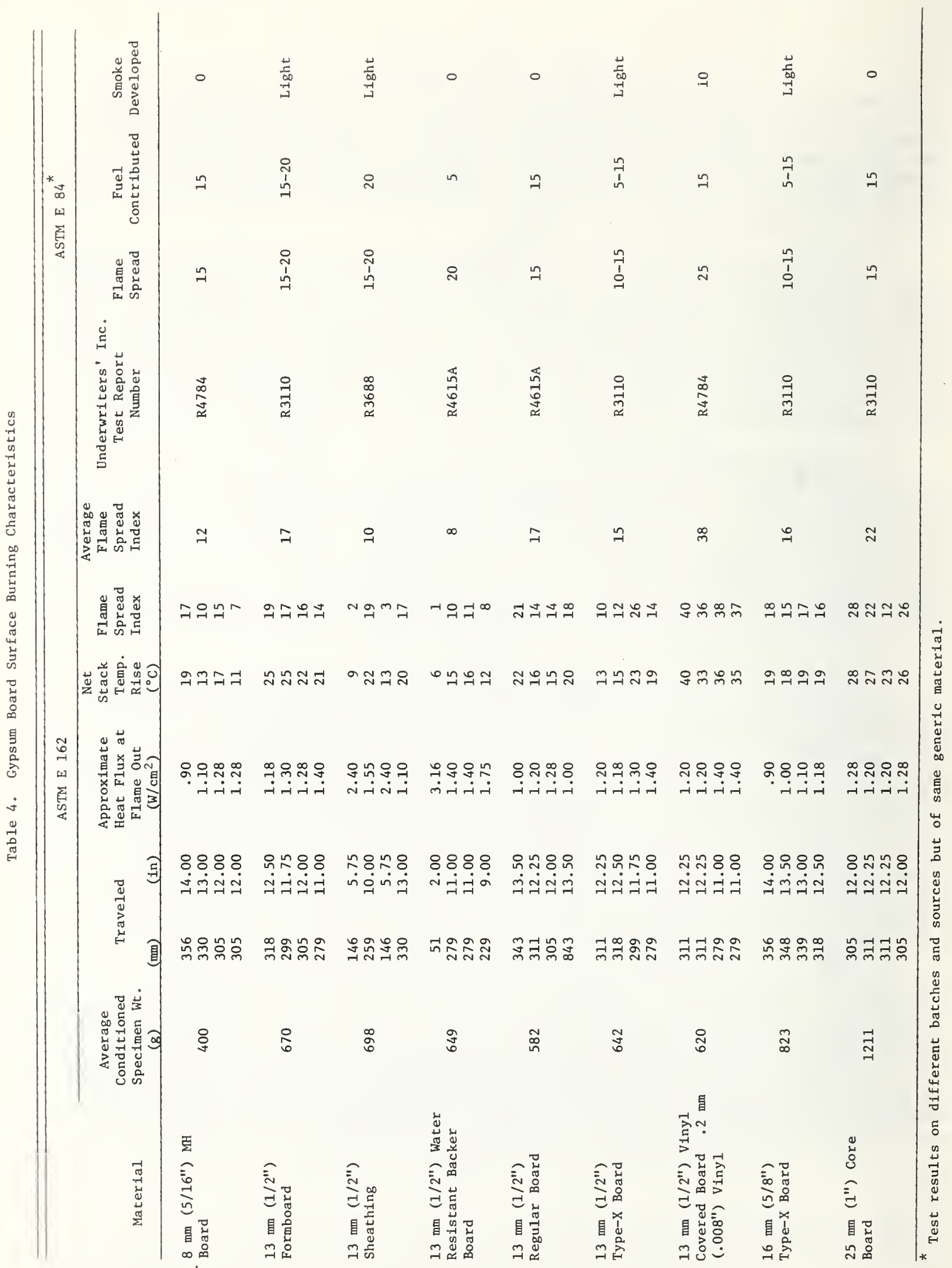




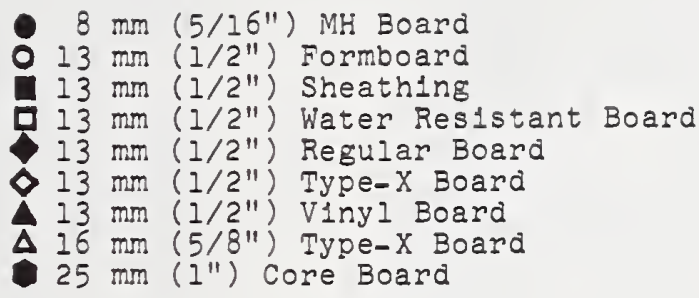

Flame

Spread

Index

ASTM E 162

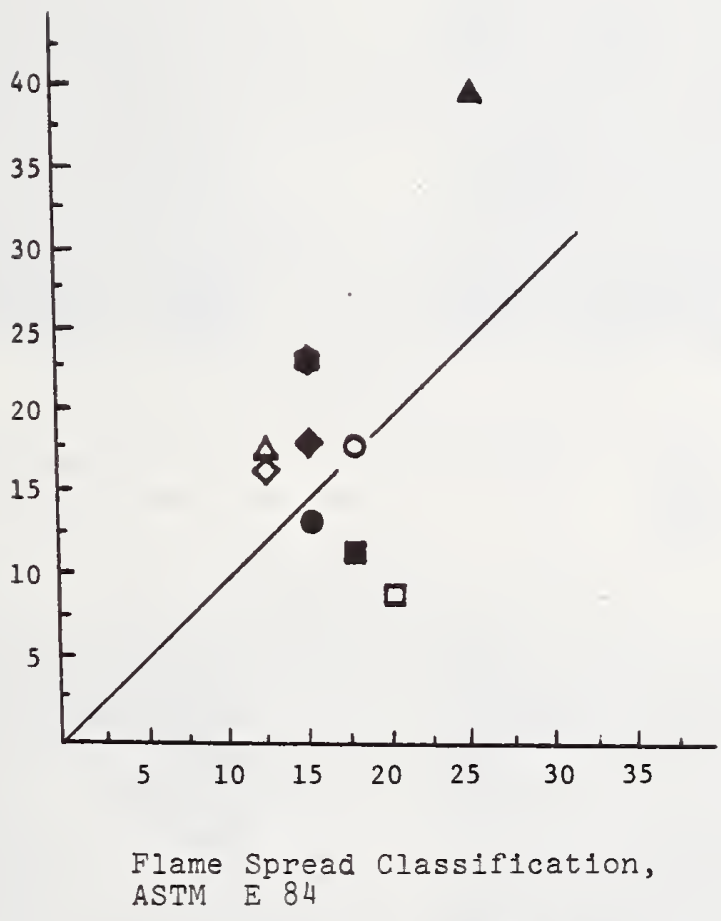

Figure 6. Variation in Flame Spread E 162 versus E 84.

\subsection{Scanning Electron Microscope Study of $13 \mathrm{~mm}$ (1/2 in) Type-X Gypsum Board}

The study was composed of two different sets of observations. The first specimen studied was not exposed to heat or fire, while the second specimen was exposed to a temperature of $750^{\circ} \mathrm{C}\left(1382^{\circ} \mathrm{F}\right)$ for one hour in a muffle furnace. The gypsum board paper ignited and burned away. The unfired board core specimen was viewed in order to determine the material's natural characteristics. The first observations of the core at 120 magnification indicated that strands of glass fiber and particles of unexpanded vermiculite were relatively evenly distributed throughout the material. Spherical voids were prevalent throughout the core. These voids varied in size from 25 to 100 microns in diameter. However, the majority of these voids averaged at about 50 microns. The average vermiculite particle size was about 200 microns square and 5 to 10 microns in thickness. The glass fiber thickness was approximately 10 microns. This can be seen in figure 7 . 
After scanning the surface of the specimen at 120 power, the magnification was increased to 800 power. At this level, it was found that gypsum crystals do actually bond to the surface of the glass fiber. Gypsum crystals were also found to be bonding to the compressed edges of the vermiculite but it did not appear to be bonded very well to the smooth end surfaces (see fig. 8). The ends of the glass fiber strands appear smooth in the 120 power picture, but at 800 power the ends of the fiber exhibited a rough appearance. The gypsum crystals which make up the major portion of the board core appeared to be quite random in length and diameter. Crystal sizes ranged from about 3 to 10 microns in length. The crystal diameter ranged between 0.25 to 0.50 microns. These crystals were bonded together into a random directional polycrystalline mass. The gypsum crystals were also viewed at 2700 power, and they appeared to have sharp well defined edges (see fig. 9).

After observing the unfired specimen, the fired specimen was viewed at 120 power as shown in figure 10. There was a vast difference between the fired and unfired specimens. The most apparent difference did not show on the surface of the crystal but was a physical change which took place within the individual crystals as a result of being exposed to the fire.

In order to evaluate this property change, it is necessary to understand the operation principal of the SEM. Upon viewing the specimen it could be seen that the crystals were receiving an electrical charge from the SEM's electron beam which impinges on the surface and penetrates the specimen. The beam interacts with the specimen and this results in the back scatter of some primary electrons and the release of secondary electrons. These free electrons are picked up by a sensor and converted into an image which is viewed on a cathoderay tube [10]. With materials that are good insulators, electrons are captured and charging occurs. Charging was not noticed on the unfired specimen. The .01 micron ( $100 \AA)$ coating of gold on the surface of the unfired specimen successfully conducted the excess electrons to ground. It is believed that because the chemically combined water was removed from the gypsum crystals during the fire exposure, the material became a better electrical insulator which allowed it to absorb (hold) a charge. This caused the surface to become extremely bright and washed out almost all surface detail. To correct

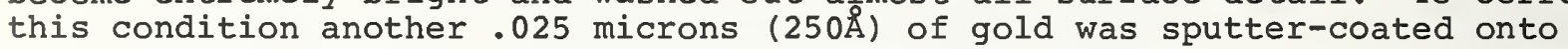
the surface of the specimen before an acceptable picture was obtained. This resulted in a total thickness of .035 microns $(350 \AA)$ of gold coating. When the specimen was viewed again only very small bright patches appeared, and this can be seen in figure 10. Several interesting observations can be made from this picture. It is evident that visible changes did occur in the crystal structure as a direct result of the specimen being exposed to a fire. In the upper right corner of the picture a vermiculite particle has expanded to a considerable length. The particle of vermiculite located at the center left also expanded but was restrained by the core. This can also be seen in figure 10 which is a 500 power magnification of the same area. This demonstrates how the vermiculite expanded and receded after cooling.

In figures 11 and 12 it is apparent that the exposed ends of the glass fiber melted into a smooth droplet shape and no longer exhibits the roughsheared surface. While examining specimens of glass fiber which were totally surrounded by the core, no deformation was noted.

The surface appearance of the gypsum crystals after being exposed to the fire showed little change in characteristics when seen at a magnification of 500 to 800 power. However, it was noted that in one area on the surface of the fire specimen the crystals appeared to be slightly rounded on the edges. This area was observed again at a magnification of $2600 \mathrm{x}$ and the surface characteristic could be better defined (see fig. 13). This picture shows that the crystals become rounded on the edges and there is some indication that the particles may have been fused. The large hole in the center of the picture is an air void, and the influence of specimen charging is seen on the right side of the picture. Two scan faults also appear on this picture which resulted from the charging of areas outside the field of view. 


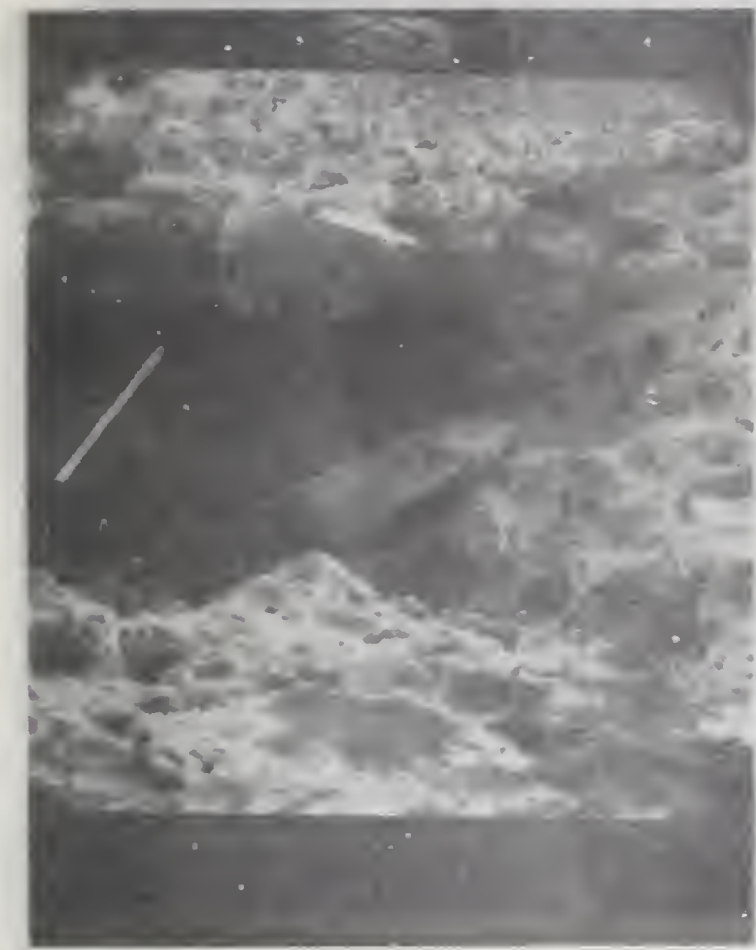

Figure 7. SEM Picture $120 \mathrm{X}$ Type-X Board Core before Fire Exposure. (Unfired Type-X $13 \mathrm{~mm}(1 / 2 \mathrm{in}))$

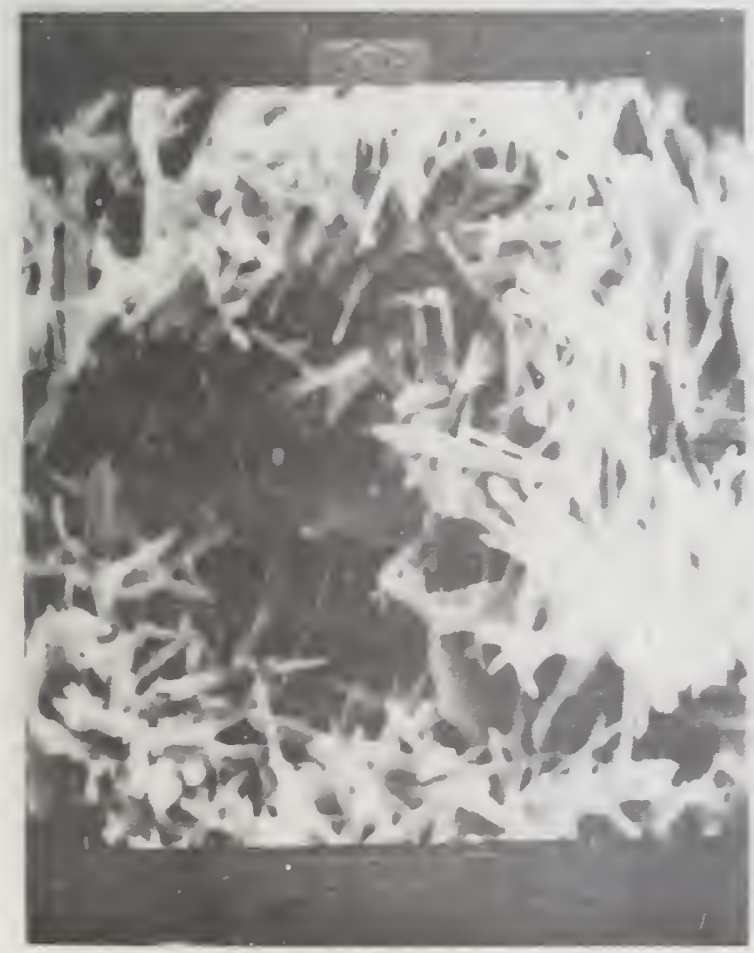

Figure 9. SEM Picture 2700X Type-X Board Core Gypsum Crystals Not Exposed to Fire

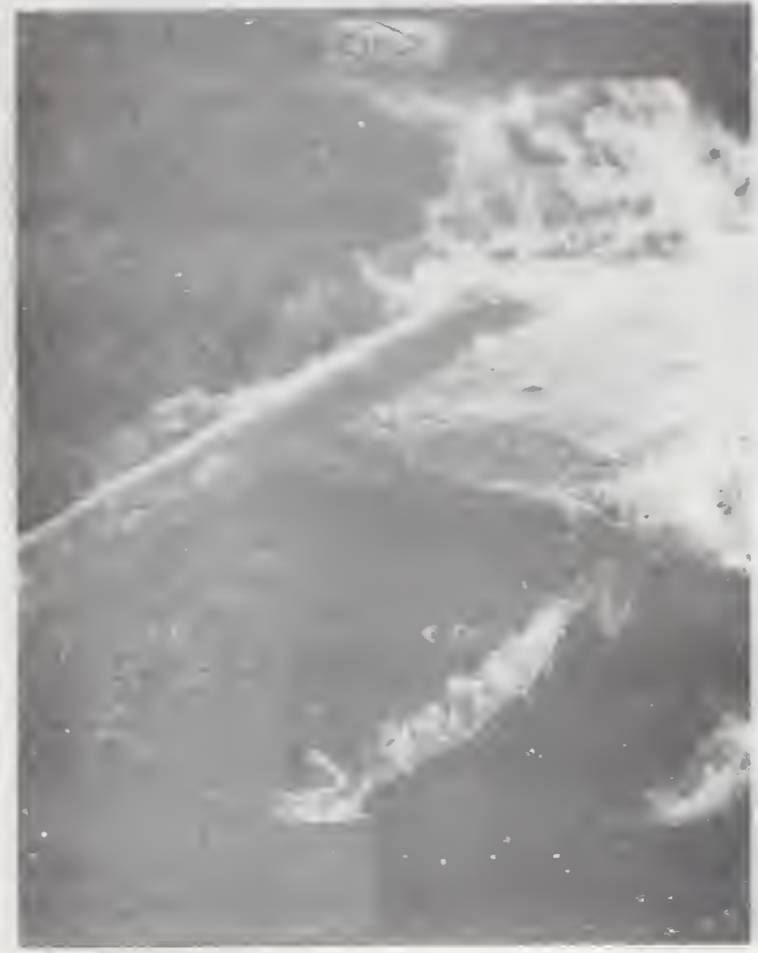

Figure 8. SEM Picture $800 \mathrm{X}$ Type-X Board Core before Fire Exposure. (Unfired Type-X $13 \mathrm{~mm}(1 / 2 \mathrm{in}))$

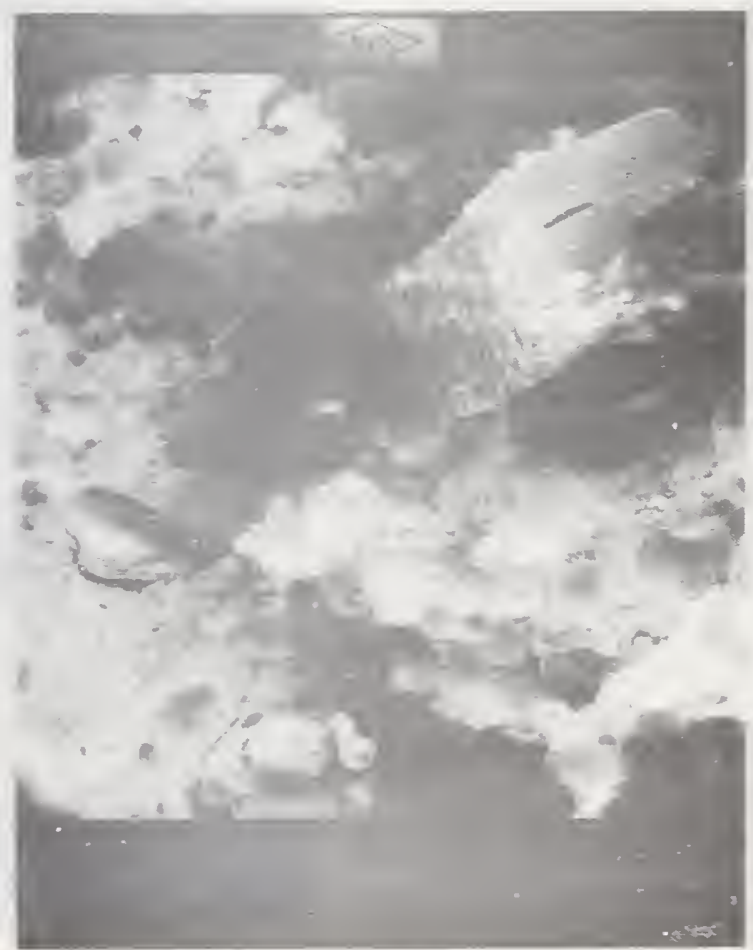

Figure 10. SEM Picture 120X Type-X Board Core after Fire Exposure 


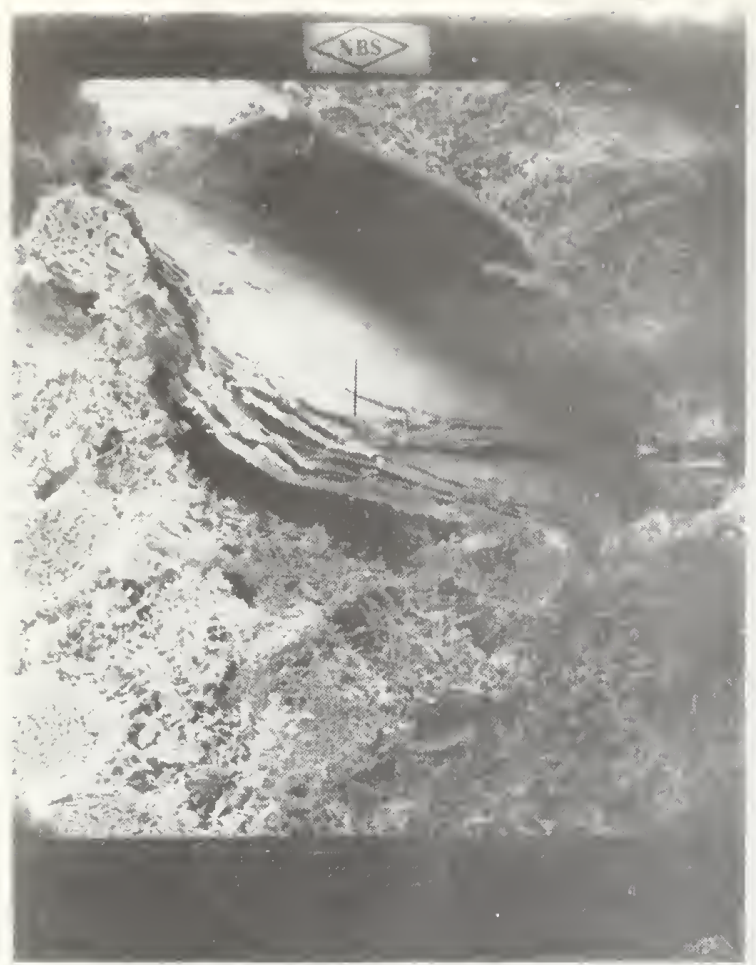

Figure 11. SEM Picture 500X Type-X Board Core after Fire Exposure

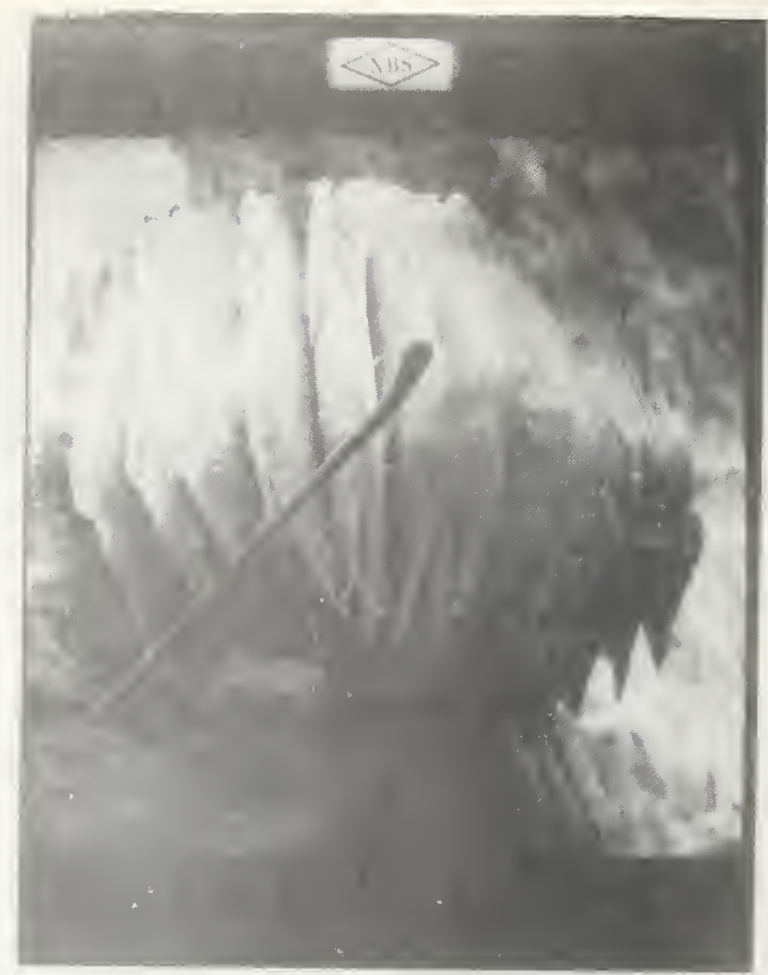

Figure 12. SEM Picture 160X Expanded Vermiculite and Melted End of Glass Fiber after Fire Exposure

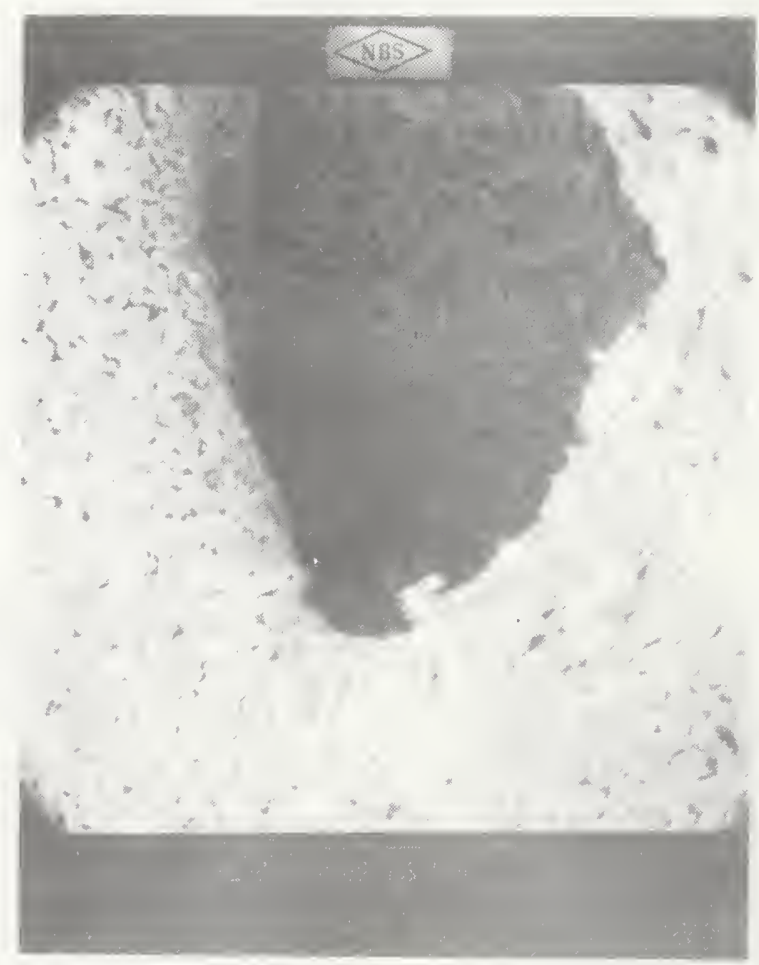

Figure 13. SEM Picture 2600X Gypsum Crystals of Board after Exposure to Fire 


\section{SUMMARY}

This paper summarizes results from four test methods used to evaluate the fire properties of nine generic gypsum board materials. The laboratory tests conducted were for potential heat, ease of ignition by flame impingement, rate of heat release, and flame spread. The potential heat of these materials ranged from $510 \mathrm{~J} / \mathrm{g}(220 \mathrm{Btu} / \mathrm{lb})$ for core board to $2670 \mathrm{~J} / \mathrm{g}$ (1150 $\mathrm{Btu} / \mathrm{lb}$ ) for water resistant backer board. The majority of the materials exhibited potential heat values that range between 700 to $1510 \mathrm{~J} / \mathrm{g}(300$ to $650 \mathrm{Btu} /(\mathrm{b})$. The ignition times experienced were from a minimum of 42 seconds with vinyl covered board to 171 seconds with gypsum sheathing. There is also an interesting correlation between the ignition time from the ease of ignition test and the time of heat contribution based on the piloted 4 $\mathrm{W} / \mathrm{cm}^{2}$ exposure in the heat release calorimeter. Generally, all of the gypsum board products fall within a narrow peak heat release span. The materials were tested using two different radiant heat flux levels without a pilot flame $4 \mathrm{~W} / \mathrm{cm}^{2}$ and $6 \mathrm{~W} / \mathrm{cm}^{2}$. Tests were also conducted at $4 \mathrm{~W} / \mathrm{cm}^{2}$ with a pilot flame above the specimen. It was found that the paper on the gypsum board would not produce a flaming ignition at an unpiloted incident flux level of $4 \mathrm{~W} / \mathrm{cm}^{2}$. The highest average peak heat release obtained was $8.2 \mathrm{~W} / \mathrm{cm}^{2}$. Flame spread tests were conducted on the ASTM E 162 apparatus and the results were compared with ASTM E 84 data. There is only limited correlation between the data obtained from the two flame spread tests. The flame spread index for the E 162 test method spanned from 8 to 38. The flame spread index for E 84 went from 10 to 25 .

A scanning electron microscope (SEM) study showed the changes which took place in the core of $13 \mathrm{~mm}$ (1/2 in) type-x gypsum board when it was exposed to fire. One of the most interesting findings was the change in electrical characteristics of the gypsum crystals after being exposed to the fire environment. The removal of much of the chemically combined water resulted in the crystals becoming better electrical insulators which allowed them to be charged by the SEM's electron beam. It was also found that the sharp edges of the crystals become rounded in the areas where there was direct flame contact, and there was some indication that the particles may have fused.

This report attempts to provide basic information on the fire resistive properties of gypsum board products. It is believed that the data presented will help to improve the understanding of how gypsum board materials react during fire exposure.

\section{ACKNOWLEDGMENTS}

Appreciation is expressed to Mr. William Kerry of the NBS, Electronics Technology Division for his help in preparing the scanning electron microscope photos used in this report, and to Mr. Roland Willard of the NBS, Center for Fire Research, for his assistance in performing various tests. 


\section{REFERENCES}

[1] Abbey, C. E., Type-X Wallboard, What It Is and Where and When It Originated, Southern Building Magazine (April 1966).

[2] Harmathy, T., A Treatise on Theoretical Fire Endurance Rating, ASTM STP 301, 10-40, American Society for Testing and Materials, Philadelphia, Pennsylvania (1961).

[3] Gross, D., Loftus, J. and Robertson, A., Potential Heat Method for Measuring the Heat Release of Materials in Building Fires, Proceedings ASTM, Vol. 61, 1336-1348 (A61).

[4] Parker, W. J. and Long, M. E., Development of a Heat Release Rate Calorimeter at NBS, ASTM STP 502, 135-151, American Society for Testing and Materials, Philadelphia, Pennsylvania (1972).

[5] Underwriters' Laboratories Incorporated, Building Materials Directory, (223-225) Underwriters' Laboratories Incorporated, Chicago, Illinois (1976).

[6] Standard Test Method for Potential Heat of Building Materials, NFPA 259-1976, National Fire Protection Association, Boston, Massachusetts (1976).

[7] Gross, D. and Loftus, J., Flame Spread Properties of Building Finish Materials, ASTM Bulletin (TP 134), American Society for Testing Materials, Philadelphia, Pennsylvania (1958).

[8] Surface Flammability of Materials Using a Radiant Heat Source, ASTM E 162-75, American Society for Testing and Materials, Philadelphia, Pennsylvania (1975).

[9] Gross, D. and Natrella, M., Interlaboratory Comparison of the Potential Heat Test Method, Fire Test Performance, ASTM STP 464, 127-152, American Society for Testing and Materials, Philadelphia, Pennsylvania (1970).

[10] Goldstein, J., Yakowitz, H., Practical Scanning Electron Microscopy, Plenum Press, New York, N. Y. (1975). 


\section{APPENDIX - COMPONENT WEIGHT FRACTIONS USED IN THE \\ CALCULATIONS OF POTENTIAL HEAT SHOWN IN TABLE 1.}

\begin{tabular}{|c|c|c|c|}
\hline Material & Face Paper & Back Paper & Core \\
\hline $\begin{array}{l}6 \mathrm{~mm}(1 / 4 ") \text { Regular } \\
\text { Gypsum Board }\end{array}$ & .070 & .073 & .856 \\
\hline $\begin{array}{c}10 \mathrm{~mm}\left(3 / 8^{\prime \prime}\right) \text { Regular } \\
\text { Gypsum Board }\end{array}$ & .047 & .049 & .904 \\
\hline $\begin{array}{c}16 \mathrm{~mm}\left(5 / 8^{\prime \prime}\right) \text { Regular } \\
\text { Gypsum Board } \\
\text { SPECIAL TESTS }\end{array}$ & .028 & .029 & .943 \\
\hline \multirow[t]{2}{*}{$\begin{array}{l}13 \mathrm{~mm}\left(1 / 2^{\prime \prime}\right) \text { Regular } \\
\text { Gypsum Board }\end{array}$} & .035 & .037 & .928 \\
\hline & Core/Face Paper & Core/Back Paper & Remaining Core \\
\hline $\begin{array}{l}13 \mathrm{~mm}\left(1 / 2^{\prime \prime}\right) \text { Regular } \\
\text { Gypsum Board } \\
3 \mathrm{~mm}\left(1 / 8^{\prime \prime}\right) \text { Core/ } \\
\text { Paper Sections }\end{array}$ & .25 & .25 & .50 \\
\hline
\end{tabular}


NBS.114A (REV.7.73)

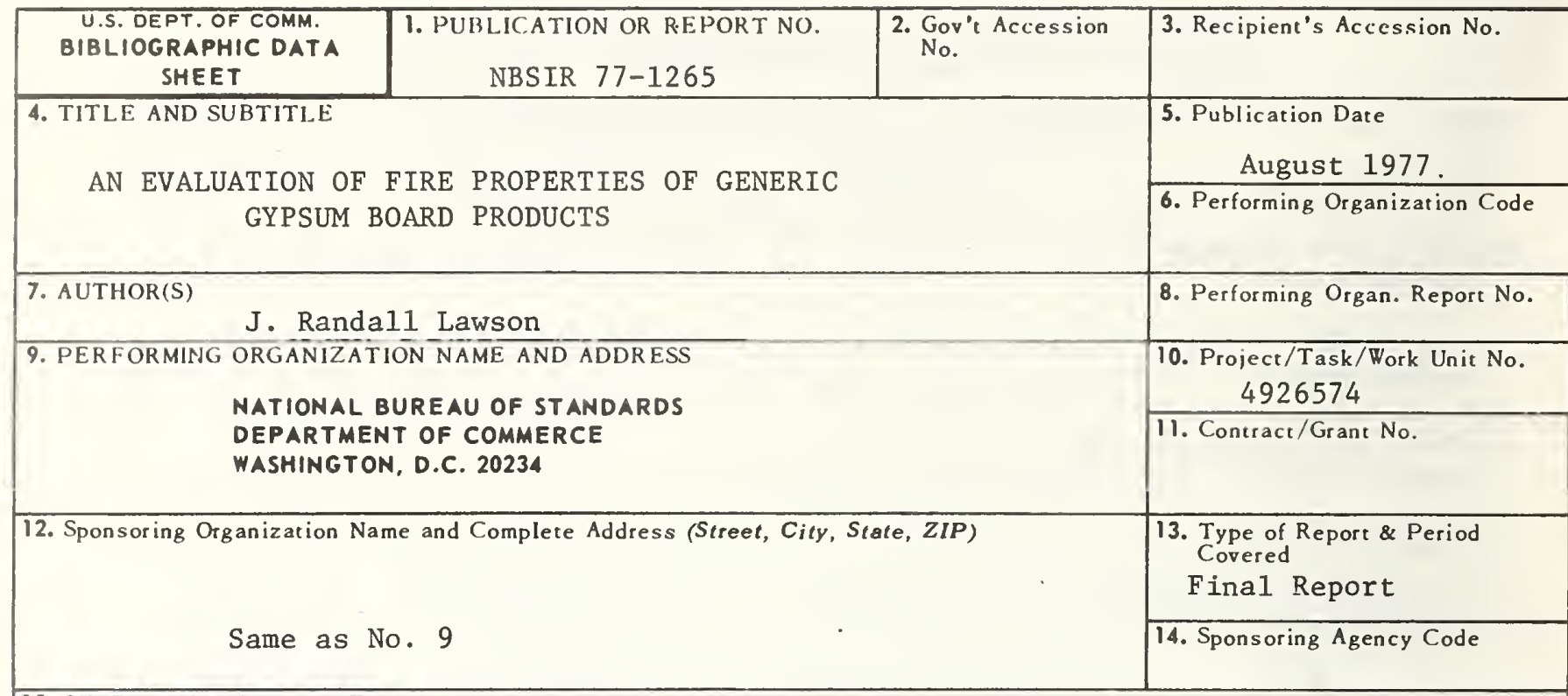

15. SUPPLEMENTARY NOTES

16. ABSTRACT (A 200-word or less factual summary of most significant information. If document includes a significant bibliography or literature survey, mention it here.)

An evaluation of the fire properties of generic gypsum board products was made in order to obtain a better understanding of the material's reaction to a fire environment. These gypsum board products are typically used in wall and ceiling assemblies throughout the United States. Four small-scale fire test methods were used in the examination of the materials' fire properties. The tests conducted were for potential heat, ease of ignition by flame impingement, rate of heat release, and rate of flame spread. All of these properties are of major importance in the design of a building. They influence the potential rate of fire growth in a room. Standard fire test methods were used for the development of data on rate of flame spread and potential heat characteristics. The ease of ignition and rate of heat release characteristics were determined by fire tests recently developed at the National Bureau of Standards. Test results showed that the potential heat for the materials examined ranged from $510 \mathrm{~J} / \mathrm{g}(220 \mathrm{Btu} / 1 \mathrm{~b})$ to $2670 \mathrm{~J} / \mathrm{g}(1150 \mathrm{Btu} / \mathrm{lb})$. The ignitability of the materials spanned from 42 to 171 seconds, while the peak heat release averages ranged from a 2.5 to $4.8 \mathrm{~W} / \mathrm{cm}^{2}$ on an unpiloted $4 \mathrm{~W} / \mathrm{cm}^{2}$ exposure and 3.9 to $8.2 \mathrm{~W} / \mathrm{cm}^{2}$ on an unpiloted $6 \mathrm{~W} / \mathrm{cm}^{2}$ exposure. The flame spread index for the materials ranged from 8 to 38 .

17. KEY WORDS (six to twelve entries; alphabetical order; capitalize only the first letter of the first key word unless a proper name; separated by semicolons) Buildings; ease of ignition; fire tests; rate of flame spread; gypsum board; potential heat; properties; rate of heat release; scanning electron microscope (SEM).

18. AVAILABILITY Xnlimited

For Official Distribution. Do Not Release to NTIS

Order From Sup. of Doc., U.S. Government Printing Office Washington, D.C. 20402, SD Cat. No. C13

Order From National Technical Information Service (NTIS) Springfield, Virginia 22151

\begin{tabular}{|l|l|}
\hline $\begin{array}{l}\text { 19. SECURITY CLASS } \\
\text { (THIS REPURT) }\end{array}$ & 21. NO. OF PAGES \\
UNCL ASSIFIED & 22. Price \\
\hline $\begin{array}{l}\text { (THIS PAGE) } \\
\text { UNCLARITY CLASS }\end{array}$ & \\
\hline
\end{tabular}



